\title{
Resolving the Dilemma of Minority Representation
}

\author{
Grant M. Hayden ${ }^{\dagger}$
}

TABLE OF CONTENTS

Introduction

I. The Representation Dilemma .................................................... 1594

A. The Battle for Minority Voting Rights ................................... 1594

1. The Right of Access to the Polls ....................................... 1595

2. The Right to an Equally Weighted Vote: Addressing "Quantitative" Vote Dilution....

3. The Right to a Meaningful Vote: Addressing "Qualitative" Vote Dilution. 1600

B. Majority-Minority Districts as a Remedy for "Qualitative"

Vote Dilution 1602

1. The Push for Majority-Minority Districts 1602

2. The Effect of Majority-Minority Districts on Minority Representation 1604

3. The Geographic Limits of Majority-Minority Districts ..... 1605

4. The Tradeoff Between Descriptive and Substantive Representation...

i. Majority-Minority Districts Benefit the Republican Party: Theoretical and Empirical Evidence 1609

ii. The Tradeoff Between Descriptive and Substantive Representation

iii. Principles that Limit the Effectiveness of MajorityMinority Districts.

II. The One Person, One Vote Standard.

A. The Popular, "Objective" Standard.

B. The Lack of Objectivity 1621

Copyright (C 2004 California Law Review, Inc. California Law Review, Inc. (CLR) is a California nonprofit corporation. CLR and the authors are solely responsible for the content of their publications.

$\dagger$ Professor, Hofstra University School of Law. B.A., M.A. University of Kansas; J.D. Stanford Law School. This Article was awarded an Honorable Mention in the Association of American Law Schools' 2004 Scholarly Paper Competition. I am grateful to June Carbone, Joanna Grossman, Peter Spiro, and Nate Persily for their helpful suggestions. Thanks as well to Sarika Kapoor and John Ellis for their research assistance. 
III. Resolving the Dilemma of Minority Representation ...................... 1625

A. A Partial Solution............................................................... 1625

B. Responses to Possible Objections ……..................................... I630

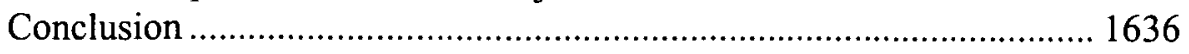




\title{
Resolving the Dilemma of Minority Representation
}

\author{
Grant M. Hayden
}

\section{INTRODUCTION}

Over the last forty years, racial and ethnic minority groups have made tremendous strides in American politics. The advances were, in large part, brought about by a series of significant changes in voting-rights law. The Voting Rights Act of 1965 finally made good on the century-old promise of the Fifteenth Amendment to ensure minorities access to the polls. The constitutional reapportionment cases of the 1960s and 1970s brought an end to the large population disparities between legislative districts that had preserved rural, white control over an increasingly urban, nonwhite nation. The right to vote was completely reformulated, and minority voters flocked to the polls, ushering in a new era in civil rights, a "Second Reconstruction."

Having secured the right to cast an equally weighted vote, voting rights advocates-with the support of the Department of Justice (DOJ), the federal agency charged with enforcement of the Voting Rights Act--turned their attention to fighting more subtle practices designed to dilute minority voting strength. They attacked practices such as at-large election schemes and racial gerrymanders using a combination of constitutional and statutory tools.

The remedy of choice, however, was the creation of majority-minority districts, districts where members of a minority group constituted an effective majority and were therefore able to elect representatives of their choice. State legislatures created a large number of these majority-minority districts during the round of redistricting following the 1990 census. These districts resulted in a significant increase in the number of African American and Hispanic representatives in Congress and in state legislatures. The changing face of our major political institutions began to make it look as if the promise of equal access and participation was finally being fulfilled.

But all was not well. There were some curious aspects to this push for additional majority-minority districts. Republican administrations, along with the Republican National Committee, vigorously supported the creation of additional majority-minority districts. This was strange, at least on 
its face, because the newly created majority-black and majority-Hispanic districts inevitably produced a black or a Hispanic Democrat. The Republicans' support was not, however, a self-sacrificing move designed to improve minority political participation. Nor was it an attempt to appeal to a new constituency. Instead, the explanation came from the nature of majority-minority districting and the effect it has on surrounding districts.

When a majority-minority district is created, the additional minority voters must be taken from somewhere, and that somewhere is the surrounding districts. This changes the racial composition not only of the new majority-minority district, but also of the districts that surround it. The newly created majority-minority district becomes, for example, more heavily black, while the surrounding districts become more heavily white. Because minority voters tend to vote Democrat, the loss of minority voters in the surrounding districts is more likely to result in the election of Republicans in those districts - unless, of course, the minority voters are replaced by white Democrats. Thus, while majority-minority districts reliably increase the number of minority officeholders, they may do so at the cost of electing candidates in surrounding districts with agendas that are at odds with minority interests.

Despite a recent shift in sentiment toward the use of coalition districts (those in which minority voters do not constitute a majority but are nonetheless able to elect candidates of their choice), the tradeoff continues to occur. This dynamic partially explains the Republican Party's rising fortunes during the 1990s. More importantly, it places minority-voting advocates in a real dilemma by forcing them to choose between additional minority officeholders and additional Democrats, between descriptive representation and substantive representation.

Ironically enough, this predicament is caused, in part, by some of the very Supreme Court rulings that once worked in favor of minority voters: the malapportionment cases of the 1960s and 1970s that imposed the one person, one vote requirement on certain state and federal legislative districts. That requirement, which mandates that districts be equally populous, soon became quite popular and, by most accounts, shifted the balance of power in the country on issues of race and civil rights. ${ }^{1}$ But requiring districts to be equally populous makes the creation of majority-minority districts a zero-sum game. Concentrating minority voters automatically draws them away from surrounding districts, which may, in the long run, dilute their overall influence on the political process. This, along with the geographically and constitutionally limited number of places to draw such districts, has effectively put a lid on minority political participation. African Americans make up only $9 \%$ of the House of Representatives despite

1. See Robert S. Erikson, Reapportionment and Policy: A Further Look at Some Intervening Variables, 219 ANnALS N.Y. ACAD. SCI. 280 (1973). 
comprising $13 \%$ of the population; Hispanics fare even worse, making up only $5 \%$ of the House despite comprising $13.3 \%$ of the population. ${ }^{2}$ The numbers are similarly dismal at the state level. ${ }^{3}$

The thesis of this Article is that strict adherence to the one person, one vote standard, especially in the context of minority-vote-dilution claims, is nonsensical. The standard itself, even outside the realm of minority voting rights, has never been adequately theorized. Its greatest advantage, according to supporters, is that it is neutral or objective, a point that is, as I and other commentators have pointed out, patently false. ${ }^{4}$ In sum, it is time for the Supreme Court to back away from strict adherence to the one person, one vote principle in minority-vote-dilution cases, eliminating the dilemma of minority representation and removing the ceiling on minority political participation.

My argument proceeds in three stages. Part I begins with a brief history of minority voting rights and then goes on to examine the rise of majority-minority districts as the remedy of choice in vote-dilution cases. Much of this Part deals with the theoretical and empirical bases for believing that such districts involve real tradeoffs in minority representation. Part II involves a close look at one of the necessary conditions of the representational dilemma: the one person, one vote standard. The standard, it turns out, is ultimately based on the same sort of normative considerations that drive other aspects of voting rights and, as such, can and should be part of the solution to the dilemma. Finally, Part III lays out such a solution. In short, I propose relaxing application of the one person, one vote rule in order to shore up minority voting power. I conclude this third Part by answering some of the most obvious objections to such a proposal.

2. Population numbers are from Jesse MCKinnon, U.S. Census Bureau, The Black Population in the United States: March 20021 (2003), and Roberto R. Ramirez \& G. Patricía de la Cruz, U.S. Census Bureau, The Hispanic Population in the United States: MARCh 2002 at 2 (2003). Congressional statistics are from DAvid A. Bositis, Joint CTr. Political \& Econ. Studies, Black Elected Officials: A Statistical Summary 2000 (2002), available at http://www.jointcenter.org/whatsnew/beo-2002/beo-map-charts/BEO-00.pdf.

3. See National Conference of State Legislatures, Numbers of African-American Legislators (2003), at http://www.ncsl.org/programs/legman/about/afrAmer.htm (last modified Dec. 29, 2003) (reporting that $8.1 \%$ of state legislators are African American); National Conference of State Legislatures, Latino Legislators (2003), at $\mathrm{http}: / / \mathrm{www} . n \mathrm{csl}$. org/programs/legman/about/Latino.htm (last modified Dec. 29,2003 ) (reporting that $2.9 \%$ of state legislators are Latino).

4. See, e.g., Grant M. Hayden, The False Promise of One Person, One Vote, $102 \mathrm{MICH}$. L. Rev. 213 (2003); Richard L. Hasen, The Supreme Court and Election LaW: Judging Equality from Baker v. Carr To Bush v. Gore 4-6 (2003). 


\section{The Representation Dilemma \\ A. The Battle for Minority Voting Rights}

The battle for minority voting rights has taken place on three fronts, each of which has given rise to a different facet of those rights. ${ }^{5}$ The first battle was for access to the ballet box. Access is at the core of the right to vote and most voting-rights movements in our history were driven by a desire to secure this aspect of the right. ${ }^{6}$ But the ability to cast a vote, however necessary, is not sufficient for meaningful political participation. Thus, in addition to access, minority voters also need to ensure that their votes are assigned the same weight as those cast by others in the electorate, in accordance with the one person, one vote standard. This second aspect of the right to vote, sometimes referred to as the right to cast a "quantitatively" undiluted vote, was at the heart of the malapportionment cases of the early 1960s. The third and final aspect of the right to vote arose out of a recognition that, in addition to the rights of access and equal weighting, minority voters could still be denied full participation in the political system through the use of devices such as at-large districting schemes and racial gerrymanders. These practices, which "qualitatively" dilute minority voting strength, are at the heart of most voting-rights jurisprudence today. But while this ongoing process of achieving equal voting rights falls into three, fairly neat analytic phases, the actual history is a bit messier, littered with stops, starts, and periods of complete regression. ${ }^{7}$ I will deal with each of these three types of voting rights claims in turn.

5. 1 borrow this basic taxonomy from Pamela S. Karlan, Maps and Misreadings: The Role of Geographic Compactness in Racial Vote Dilution Litigation, 24 HARv. C.R.-C.L. L. REv. 173, 176 (1989). She later revised this classification, describing the right to votc as involving participation, aggregation, and governance. See Pamela S. Karlan, The Rights To Vote: Some Pessimism About Formalism, 71 TEx. L. Rev. 1705, 1709-20 (1993). 1 organize this discussion using the earlier classification because I want to separate out the two principal aspects of "aggregation": the right to a quantitatively undiluted vote versus the right to a qualitatively undiluted vote. But the addition of "governance" will certainly be useful later in this discussion, for the dilemma of minority representation is one that involves a forced tradeoff between aggregation and governance.

6. For a recent discussion of the expansions and contractions in the right to vote and their social, economic, and political causes, see Alexander Keyssar, The Right to Vote: The Contested History of Democracy in the United STATEs (2000). For a survey of the right to vote early in the nation's history, see Marchette Chute, The First Liberty: A History of the Right to Vote in america, i619 - I850 (1969); and Chilton Williamson, American Suffrage: From Property to DemoCRACY, 1760 - I860 (1960). For later developments of the right to vote, with emphasis on minority voting rights, see Bernard Grofman et al., Minority RePresentation and the Quest For Voting Equality (1992); J. Morgan Kousser, The Shaping of Southern Politics: Suffrage Restriction and the Establishment of the ONE-PARTY SOUTh, i 880 - 19 Io (1974); Steven F. Lawson, BlaCk Ballots: Voting Rights IN the South, I944 - I 969 (1976); and Quiet Revolution in the South: The Impact of the Voting Rights ACt, 1965 - 1990 (Chandler Davidson \& Bernard Grofman eds., 1994).

7. See KEYSSAR, supra note 6, at xvii-xxiv. 


\section{The Right of Access to the Polls}

For African Americans, access to the ballot box was initially secured through the post-Civil War amendments to the Constitution-in particular, the Fifteenth Amendment-and several federal statutes designed to enforce the new constitutional guarantees. ${ }^{8}$ As a result, large numbers of blacks voted in the South in the 1870 s and 1880 s, and black candidates experienced a remarkable degree of success. ${ }^{9}$ The postwar flowering of black political participation, however intense, was short lived. The North's rising indifference to the plight of black voters was signaled by a series of 1876 Supreme Court cases that gutted the central statutes used to enforce the guarantees provided by the Fifteenth Amendment. ${ }^{10}$ This, coupled with the withdrawal of military troops from the South under the Compromise of 1877, crippled the ability of Congress to enforce the Fifteenth Amendment. " Southern whites responded with a series of escalating measures designed to keep black voters away from the polls, including force and ballot-box fraud. ${ }^{12}$ By the turn of the century, the Southern white political leadership closed the book on black participation altogether with a series of state statutory and constitutional provisions imposing facially neutral devices, such as poll taxes and literacy tests, designed to prevent poor and illiterate blacks from voting. ${ }^{13}$ As a result, black registration and voting in the South plummeted. In Louisiana alone, the number of registered blacks dropped from more than I30,000 in 1896 to fewer than 1500 by $1904 .{ }^{14}$

The level of black political participation remained stagnant until passage of the Voting Rights Act of $1965 . .^{15}$ The Act, which was designed to enforce the original Fifteenth Amendment guarantees, became one of the most successful pieces of civil-rights legislation in history. ${ }^{16}$ Section 2 of the Act tracked the language of the Fifteenth Amendment and prohibited

8. For a discussion of the passage of the Fifteenth Amendment, see William Gillette, The Right to Vote: Politics and the Passage of the Fifteenth Amendment (1965); and Keyssar, supra note 6, at 93-104. For some background on the various statutes designed to enforce the Fifteenth Amendment, see KEYSSAR, supra note 6, at 106; and GroFMAN ET AL., supra note 6, at 5.

Before the Civil War, slaves could not vote, and free blacks were rarely able to meet propertyholding and taxpaying requirements. See KeYsSAR, supra note 6, at 55 . By the middle of the nineteenth century, states had abolished most of these requirements but adopted more formal race exclusions. See id. at 55-59.

9. See Grofman ET Al., supra note 6, at 5 .

10. The cases included United States v. Cruikshank, 92 U.S. 542 (1876), and United States $v$. Reese, 92 U.S. 214 (1876). See KEYSSAR, supra note 6, at 107; GrofmaN ET AL., supra note 6, at 6-7.

11. See Grofman et Al., supra note 6, at 7 .

12. See id. at 5-6.

13. See KousSER, supra note 6; see also KeYSSAR, supra note 6, at 111-16; GrofMAN ET AL., supra note 6 , at 8-10.

14. KEYSSAR, supra note 6, at 114-15.

15. See Grofman ET AL., supra note 6; LAwson, supra note 6, at 10 . On the passage of the Voting Rights Act of 1965, see LAwSON, supra note 6, at 288-328; KEYSSAR, supra note 6, at 262-64.

16. See KEYSSAR, supra note 6, at 264-65. 
voting qualifications or practices that denied or abridged the right of any citizen to vote on account of race or color. ${ }^{17}$ The Act also contained several provisions that swept aside many of the facially race-neutral devices used to keep minority voters from the polls. Section 4 used a neutral formula to select certain jurisdictions for special treatment. ${ }^{18}$ These "covered" jurisdictions, including most of the worst offenders in the South, were subject to two principal constraints. First, they were prohibited from using literacy tests, character tests, or other devices used to discriminate against minority voters. ${ }^{19}$ Second, section 5 of the Act required them to submit any proposed change in election procedures to the Attorney General or to the federal district court for the District of Columbia for "preclearance" before making the change. ${ }^{20}$

The Voting Rights Act had the immediate effect of opening the polls to blacks and other minority groups. ${ }^{21}$ In the covered jurisdictions, the percentage of eligible blacks registered rose from $29 \%$ to over $52 \% .^{22}$ In 1970 , the Act was amended to extend the ban on literacy and character tests nationwide and, in 1975, to extend protection to language minorities. ${ }^{23}$ Over succeeding decades, the level of minority voter participation continued its upward climb, slowly reducing the gap between minority and white voter registration. ${ }^{24}$ This success, though, was limited, because mere access to the polls guarantees nothing in a representative democracy.

\section{The Right to an Equally Weighted Vote: Addressing "Quantitative" Vote Dilution}

The second aspect of the right to vote-the right to cast an equally weighted vote-developed in the $1960 \mathrm{~s}$, around the same time that minority voters finally secured access to the ballot box. As with access, however, it was merely the tail end of a much longer story. The idea that representatives should be elected by people casting equally weighted votes was a central idea from the country's inception. ${ }^{25}$ Then, for more than half a century,

\footnotetext{
17. 42 U.S.C. $\$ 1973$ (a) (2000).

18. 42 U.S.C. $\$ 1973$ b(b) (2000); see also infra note 53.

19. 42 U.S.C. $\$ 1973(2000)$.

20. 42 U.S.C. $\$ 1973$ c (2000).

21. See QUiET Revolution IN THE South, supra note 6; LAWSON, supra note 6, at 329-52.

22. See Grofman, ET AL., supra note 6, at 22 .

23. See KeysSAR, supra note 6, at 265. "Language minorities" include people who are American Indian, Asian American, Alaskan Natives or people of Spanish heritage. 42 U.S.C. $\$$ 19731(c)(3) (2000). The Supreme Court had already recognized Hispanics as a racial minority under the Constitution. See White v. Regester, 412 U.S. 755, 767-69 (1973).

24. See GROFMAN ET AL., supra note 6, at 22 .

25. See Gordon E. Baker, The Reapportionment Revolution: Representation, Political Power, ANd the Supreme Court 16-22 (1966); Robert B. MCKay, Reapportionment: The LaW and Politics of Equal Representation 16-29 (1965); Gordon E. Baker, One Person, One Vote: "Fair and Effective Representation"?, in REPRESENTATION AND MISREPRESENTATION: LeGISLATIVE Reapportionment iN Theory and Practice 71, $72-74$ (Robert A. Goldwin ed., 1968).
} 
this principle of political equality was discounted by most state legislatures, ${ }^{26}$ only to be rediscovered and reapplied in the reapportionment cases of the $1960 \mathrm{~s}$ and $1970 \mathrm{~s} .^{27}$

While there was nothing in the original Constitution about equally weighted votes, there is plenty of evidence that such representation was the norm at the time the country was founded. There are indications, for example, that the framers of the Constitution intended members of the House to be elected according to such principles. ${ }^{28}$ In addition, the original constitutions of many of the first thirteen states, ${ }^{29}$ and most of the states subsequently admitted to the union, ${ }^{30}$ provided for population-based apportionment for both houses of their legislatures. So while there was no federal, constitutional acknowledgment of a right to cast an equally weighted vote (or much else on the voting rights front), the sentiment behind that right was an intrinsic part of many of our political institutions.

The move away from population-based districting began after the Civil War, ${ }^{31}$ but really picked up steam in the first half of the twentieth century. Decade after decade, oftentimes in violation of their own state constitutions, state legislators refused to redraw district boundaries in the face of census data showing significant demographic shifts from rural areas to the cities. ${ }^{32}$ The movement to the cities was driven, in large part, by the

26. See BAKER, supra note 25, at 24-31; MCKAY, supra note 25, at 49-53.

27. See Karcher v. Daggett, 462 U.S. 725, 728 (1983) (rejecting a New Jersey congressional districting plan that involved a $.6984 \%$ maximum deviation); Kirkpatrick v. Preisler, 394 U.S. 526, 528-29 (1969) (rejecting a Missouri congressional districting plan that involved a $5.97 \%$ maximum deviation); Reynolds v. Sims, 377 U.S. 533 (1964) (applying the one person, one vote requirements to state legislative districts); Wesberry v. Sanders, 376 U.S. 1 (1964) (applying the one person, one vote requirements to congressional districts); Bakcr v. Carr, 369 U.S. 186 (1962) (finding differences in state legislative district sizes to be a justiciable issue).

28. See Andrew Hacker, Congressional Districting: The Issue of Equal REPRESENTATION 6-14 (rev. ed. 1964). The evidence comes from a wide range of sources, including the Constitution, the Philadelphia Convention, the Federalist Papers, and the state ratifying conventions. Id.; see also Wesberry, 376 U.S. at 7-18 (explaining that the historical context of the constitutional requirement that representatives be chosen "by the People of the several States" demands use of the equiproportional standard). But see Wesberry, 376 U.S. at 30-39 (Harlan, J., dissenting) (arguing that the historical record does not support the constitutionalization of the equiproportional standard).

29. See BAKER, supra note 25, at 20; Baker, supra note 25, at 72-73; see also MCKAY, supra note 25, at 17-19. But see Robert G. Dixon, JR., Democratic Representation: Reapportionment in LAW AND Politics 60-64 (1968); Robert G. Dixon, Jr., Reapportionment in the Supreme Court and Congress: Constitutional Struggle for Fair Representation, 63 MICH. L. REv. 209, $239-42$ (1964). These contrasting views are based upon conflicting interpretations of what it meant for a state constitution to call for apportionments based predominantly on population. For a discussion of the issue, see Baker, supra note 25 , at 73.

30. See McKaY, supra note 25, at 16-19, 24-25. From 1790 to 1889 , no state was admitted that did not provide for representation based principally on population. Id. at 24-25.

31. See William J.D. Boyd, Reapportionment: Problems, Prospects, and Probabilities, in Representation and MisRepresentation: Legislative ReapPortionment in Theory and PraCtiCe 115, 115 (Robert A. Goldwin ed., 1968).

32. See BAKER, supra note 25, at 24-31; MCKAY, supra note 25, at 49-53. 
migration of rural blacks and the immigration of Europeans ${ }^{33}$ As a result, voters living in the large and growing urban areas, who were disproportionately members of minority groups, had their votes numerically diluted. And these voters had little way to redress the problem: state legislators were not about to redistrict themselves out of power, and the Supreme Court declared the issue a nonjusticiable political question. ${ }^{34}$ The numerical disparities, then, just kept growing.

By the 1960s, when it became apparent that there was no ready solution to this legislative logjam, the Supreme Court reconsidered the question and came to a different conclusion, taking its first (and, some would argue, fatal) step into the political thicket. In 1962, the Court found that the Tennessee legislature's failure to redistrict in the face of demographic change gave rise to a justiciable issue under the Fourteenth Amendment. ${ }^{35}$ The judicial floodgates were now open. The following year, the Court first declared the basic standard for assessing numerical vote dilution: one person, one vote.$^{36} \mathrm{~A}$ year later, the Court applied the standard to state legislative districts ${ }^{37}$ and congressional districts. ${ }^{38}$

While the early one person, one vote cases established a numerical ideal, they did not clearly define the range of permissible variation. ${ }^{39}$ In those first few cases, though, the Court signaled that it was heading in different directions on this question with respect to state and federal elections. In Reynolds $v$. Sims, the court found that one's right to vote for state legislators was unconstitutionally impaired when "its weight is in a substantial fashion diluted" as compared to voters in other parts of the state. ${ }^{40}$ In Wesberry, by contrast, the Court held that one's vote for federal

33. See C. Herman Pritchett, Representation and the Rule of Equality, in REPRESENTATION AND Misrepresentation: Legislative Reapportionment in Theory and Practice, supra note 25 at 1 , 3.

34. Colegrove v. Green, 328 U.S. 549 (1946).

35. Baker v. Carr, 369 U.S. 186 (1962).

36. See Gray v. Sanders, 372 U.S. 368, 381 (1963) ("The conception of political equality from the Declaration of Independence, to Lincoln's Gettysburg Address, to the Fifteenth, Seventeenth, and Nineteenth Amendments can mean only one thing - one person, one vote.").

37. Reynolds v. Sims, 377 U.S. 533 (1964).

38. Wesberry v. Sanders, 376 U.S. 1 (1964).

39. Variation from the one person, one vote ideal (sometimes called the maximum population deviation) is calculated for single-member districts using the following steps. First, calculate the ideal district size by dividing the apportionment base (usually population) by the number of districts. Then, add the percentage excess of the largest district over the ideal district size to the percentage deficit of the smallest district under the ideal district size. That sum is the maximum population deviation. This method is most clearly shown in Chapman v. Meier, 420 U.S. 1, 21-22 (1975).

If, for example, we are dividing a population of 30,000 among three legislative districts, our ideal district size is 10,000 . If the largest and smallest districts actually have a population of 11,500 and 8000 , the maximum total deviation is $35 \%$ ( $15 \%$ deviation upward plus $20 \%$ deviation downward).

40. 377 U.S. at 568 . Though the Court later conceded that it may not be possible to draw district lines witb "[m]athematical exactness or precision," id. at 577 , better census data and more powerful computers later made such precision a possibility. See Samuel 1ssacharoff, Judging Politics: The Elusive Quest for Judicial Review of Political Fairness, 71 TEx. L. Rev. 1643, 1654 (1993). 
representatives must, "as nearly as is practicable," be worth that of other voters. ${ }^{41}$ The Court later made clear that it would not hold state and local election districts to the same standard as congressional districts. State and local districts were allowed to deviate up to $10 \%$ without justification ${ }^{42}$ and slightly more when suitably justified ${ }^{43}$ Congressional districts, on the other hand, were increasingly held to a strict standard where almost no deviation from the ideal district population passed constitutional muster. ${ }^{44}$

The one person, one vote standard soon became part of the underlying structure of federal, state, and local redistricting decisions. The rural, white minority that controlled state legislatures (and, hence, controlled federal and state redistricting decisions) was suddenly unable to sit back and allow the numerical disparities between districts to grow. As a result, in a few, short years the tremendous inequalities in district populations-inequalities that had a detrimental effect on minority representation-were eliminated from the political landscape. ${ }^{45}$ Minority voters now had the right to cast ballots and the right to have their votes assigned the same weight as those of other voters. But while these rights seemed to be necessary prerequisites to meaningful political participation, they were not sufficient: minority voters still faced the possibility of having their votes qualitatively diluted.

41. 376 U.S. at $7-8$.

42. In Brown v. Thomson, the Court stated:

[M]inor deviations from mathematical equality among state legislative districts are insufficient to make out a prima facie case of invidious discrimination under the Fourteenth Amendment so as to require justification by the State. Our decisions have established, as a general matter, that an apportionment plan with a maximum population deviation under $10 \%$ falls within this category of minor deviations.

462 U.S. 835, 842 (1983) (internal citations and quotations omitted). See also Connor v. Finch, 431 U.S. 407, 418 (1977); Gaffney v. Cummings, 412 U.S. 735, 75I (1973); White v. Regester, 412 U.S. 755, 764 (1973). But see Cox v. Larios, 124 S. Ct. 2806 (2004) (summarily affirming a district court ruling that Georgia's state legislative redistricting plan, despite having a maximum deviation of $9.98 \%$, nonetheless violated the one person, one vote requirement of the Equal Protection Clause).

43. See Mahan v. Howell, 4I0 U.S. 315, 324-25 (1973) (upholding a Virginia state redistricting plan with a maximum deviation of $16.4 \%$ on the basis of the state's interest in preserving the integrity of political subdivision boundary lines), amended by 411 U.S. 922 (1973).

44. See, e.g., Karcher v. Daggett, 462 U.S. 725, 728 (1983) (rejecting a New Jersey congressional districting plan that involved a $.6984 \%$ maximum deviation); Kirkpatrick v. Preisler, 394 U.S. 526, 528-29 (1969) (rejecting a Missouri districting plan that involved a 5.97\% maximum deviation).

45. While the lack of effective minority representation was primarily a result of disenfranchisement, the lack of numerical voting power also played a role. On the success of the reapportionment cases in restoring majoritarian rule to our political institutions, see, for example, Lani Guinier \& Pamela S. Karlan, The Majoritarian Difficulty: One Person, One Vote, in REASON AND Passion: Justice Brennan's Enduring Influence 207, 211 (E. Joshua Rosenkranz \& Bernard Schwartz eds., 1997); Jesse H. Choper, Consequences of Supreme Court Decisions Upholding Individual Constitutional Rights, $83 \mathrm{MiCH}$. L. REv. 1, 90-94 (I984) (reviewing studies about the impact of state reapportionment on expenditures in suburban and urban areas, minority representation, and party strength); and Nathaniel Persily et al., The Complicated Impact of One Person, One Vote on Political Competition and Representation, 80 N.C. L. REv. 1299 (2002) (examining the effect of the reapportionment decisions on various aspects of representation). 


\section{The Right to a Meaningful Vote: Addressing "Qualitative" Vote Dilution}

Even with a guarantee of equally weighted votes, meaningful minority participation may be thwarted by qualitatively diluting minority votes. State legislatures have used a variety of schemes to dilute the black and Hispanic vote, including at-large elections, anti-single-shot laws, reductions in the size of legislative bodies, racial gerrymandering, and exclusive slating. ${ }^{46}$ To take one example, one may gerrymander district lines in several different ways to dilute minority voting strength. ${ }^{47} \mathrm{~A}$ minority group that is large enough to constitute a majority in a single-member district may be "cracked," or divided among various districts such that it is a majority in none of them. ${ }^{48}$ Or a minority group sufficiently large to constitute majorities in two single-member districts may be "packed" into one district, so that its members, while they make up a supermajority in that one district, are able to elect only one representative of their choosing. ${ }^{49}$ In either case, the minority group may be unable to elect a representative of its choice despite the fact that all of its members had the right to cast an equally weighted vote.

These tools of qualitative vote dilution were not invented in response to the gains in black political participation in the 1960s; most had been used, very effectively, beginning in the nineteenth century. For most of those years, however, the white majority kept members of minority groups out of the political process by directly denying their members access to the polls or numerically diluting their votes. But once those two strategies were foreclosed by Congress and the Court, the focus shifted to more subtle attempts to qualitatively dilute minority votes. Those who drafted and interpreted the Voting Rights Act, however, anticipated this response.

The first line of defense against attempts to qualitatively dilute the black vote came under section 5 of the Voting Rights Act. ${ }^{50}$ Section 5 requires the Attorney General or the United States District Court for the District of Columbia to "preclear" any proposed changes to "any voting qualification or prerequisite to voting, or standard, practice, or procedure with respect to voting" in certain jurisdictions. ${ }^{51}$ The Supreme Court applied this section to changes that qualitatively diluted voter power as well

46. See, e.g., Grofman ET AL., supra note 6, at 23-24.

47. See Frank R. Parker, Racial Gerrymandering and Legislative Reapportionment, in MINORITY Vote Dilution 85, 86-99 (Chandler Davidson ed., 1984).

48. See id.

49. See id. The Supreme Court has discussed the strategies of cracking and packing in several opinions. See, e.g., Thomburg v. Gingles, 478 U.S. 30, 46 n. 11 (1986).

50. 42 U.S.C. $\$ 1973$ c (2000).

51. Id. 
as those that disenfranchised minority voters, thus providing a potent weapon to attack more subtle forms of discrimination. ${ }^{52}$

Section 5, however, was limited in a couple of respects. First, it only applied to a certain number of targeted jurisdictions. ${ }^{53}$ Second, it only applied to changes in voting practices. ${ }^{54}$ Thus, dilutive practices that existed prior to the passage of the Voting Rights Act (or before a jurisdiction's inclusion in section 5 coverage) were not subject to these requirements. ${ }^{55}$ This second limitation, however, did not have much effect when it came to districting because all redistricting plans involved covered changes. Nevertheless, plaintiffs were somewhat at the mercy of the preclearance decisions made by the DOJ. This meant that voting-rights advocates sometimes looked elsewhere for a means of attacking dilutive practices.

Given their success in the one person, one vote cases, the first place voting-rights advocates turned was to the Constitution. The early malapportionment cases generally recognized that vote dilution was actionable under the Equal Protection Clause. ${ }^{56}$ Though the early cases focused on claims of quantitative dilution, the cases that followed made clear that qualitative dilution claims were actionable as well. ${ }^{57}$ Many of these cases targeted the dilutive effect of multimember districts and most were analyzed under a combination of factors set forth by the Supreme Court and the Fifth Circuit Court of Appeals. ${ }^{58}$ Those standards changed rather remarkably, however, in 1980, when the Court decided City of Mobile v. Bolden. ${ }^{59}$

The Bolden Court held that parties alleging qualitative vote dilution must demonstrate that the challenged practice was established or

52. See Allen v. State Bd. of Elections, 393 U.S. 544, 569 (1969) (holding that Virginia statutes changing elections from district to at-large and making certain county positions appointed rather than elected were subject to section 5 preclearance).

53. Section 4(b) of the Voting Rights Act describes the covered jurisdictions as those meeting the following criteria: (1) the jurisdiction maintained a test or device as a precondition for registering or voting as of November 1, 1964, and (2) less than $50 \%$ of the voting-age population was registered to vote on November 1, 1964, or less than $50 \%$ of the voting-age population voted in the November 1964 presidential election. 42 U.S.C. $\$ \$ 1973 \mathrm{~b}(\mathrm{~b}), 1973 \mathrm{c}$ (2000). The test was designed to target Southern states with a history of discrimination and initially covered Alabama, Georgia, Louisiana, Mississippi, South Carolina, Virginia, and parts of North Carolina.

54. $\S 1973 \mathrm{c}$.

55. Id.; Beer v. United States, 425 U.S. 130, 138 (1976) (holding that "[t]he language of $\S 5$ clearly provides that it applies only to proposed changes in voting procedures").

56. See, e.g., Reynolds v. Sims, 377 U.S. 533, 565-66 (1964).

57. See. e.g., White v. Regester, 412 U.S. 755, 765-70 (1973) (holding that despite nearly equally sized districts, multimember voting districts excluded minority participation and thus violated the Equal Protection Clause).

58. The factors, known as the White/Zimmer factors, came out of White v. Regester, 412 U.S. at 765-67, and Zimmer v. McKeithen, 485 F.2d 1297, 1305-06 (5th Cir. 1973), aff d sub nom. East Carroll Parish Sch. Bd. v. Marshall, 424 U.S. 636 (1976).

59. 446 U.S. 55 (1980) (plurality opinion). 
maintained with discriminatory intent. ${ }^{60}$ The intent requirement was applied to suits under either the Fourteenth or Fifteenth Amendment. And since the Voting Rights Act was said to add nothing to the constitutional cause of action, the intent requirement also applied to section 2 of the Voting Rights Act. ${ }^{61}$ Qualitative vote-dilution claims ground to a halt.

While Congress could do nothing about the Court's new constitutional position, it did have control over the Voting Rights Act. When the Act came up for reauthorization the year following Bolden, Congress took that opportunity to decouple section 2 claims from constitutional claims and specifically did not require proof of discriminatory intent as part of a section 2 claim. ${ }^{62}$ The Supreme Court issued its first interpretation of the statutory changes a few years later, ${ }^{63}$ and section 2 became the weapon of choice in voting-rights litigation.

Thus, even though African Americans and members of other minority groups had made tremendous strides in securing the right to vote, there was still some work left to be done. They had greater access to the ballot box. They had the assurance that a vote cast there would be quantitatively undiluted-that is, it would be given the same numeric weight as other ballots. And, yet, it was still possible that the vote could be qualitatively diluted such that it could not be combined with votes by other members of the minority group in ways that allow the group to elect a representative of its choice. Such dilution was attacked through sections 2 and 5 of the Voting Rights Act. Those actions, in turn, began to focus on the use of majorityminority districts as a remedy for qualitative vote dilution.

\section{B. Majority-Minority Districts as a Remedy for "Qualitative" Vote Dilution}

\section{The Push for Majority-Minority Districts}

When it came to the problem of minority electoral success, there was a confluence of events that made majority-minority districts the solution of choice. ${ }^{64}$ The Congressional Black Caucus pushed for such districts in

60. See id. at 90 (Stevens, J., concurring). The intent requirement came on the heels of the Court's similar requirement for more ordinary Equal Protection claims announced in Washington $v$. Davis, 426 U.S. 229, 238-42 (1976).

61. Bolden, 446 U.S. at $60-62$.

62. See 42 U.S.C. $\$ \$ 1971$ to $1973 \mathrm{bb}-1$ (2000).

63. Thomburg v. Gingles, 478 U.S. 30 (1986)

64. Majority-minority districts refer, most simply, to political districts in which blacks, Hispanics, or members of some other racial or ethnic minority constitute a majority. Sometimes the term is used to refer to when minority members make up a simple arithmetic majority; other times, because minority registration or turnout rates may be lower, it is used to refer to a district with a somewhat higher proportion of minorities such that they constitute an effective voting majority. See Bernard Grofman et al., Drawing Effective Minority Districts: A Conceptual Framework and Some Empirical Evidence, 79 N.C. L. REv. 1383, 1384-85 (2001); Richard H. Pildes, Is Voting-Rights Law 
order to bolster its ranks. ${ }^{65}$ Civil-rights lawyers and the press put pressure on state legislatures to create them. ${ }^{66}$ And, looming in the background, there were the federal and state obligations under the Voting Rights Act. ${ }^{67}$

Section 5 of the Voting Rights Act became an important method of securing majority-minority districts. Section 5 , remember, requires selected jurisdictions to "preclear" any changes in voting practices through the DOJ or the federal district court for the District of Columbia. After it became clear that public officials in some Southern states were ready to resist the Voting Rights Act not just with changes in voter qualifications, but also with changes in entire election schemes (such as switching from singlemember to at-large voting schemes), the Supreme Court sanctioned an expanded view of section 5 that captured such changes. ${ }^{68}$ Over time, the DOJ became more and more aggressive with the preclearance provisions. By 1995, when the Supreme Court decided Miller v. Johnson, it became apparent that the DOJ was attempting, through its preclearance power, to greatly increase and even maximize the number of majority-minority districts. $^{69}$

Section 2 lawsuits and the threat of such lawsuits were also a factor in producing majority-minority districts. In Thornburg $v$. Gingles, the Supreme Court's first interpretation of the I 982 amendments to section $2,^{70}$ the Court set out a three-pronged test for assessing when protected minorities have "less opportunity than other members of the electorate to participate in the political process and to elect representatives of their choice."71 First, the minority group must be sufficiently large and geographically compact to constitute a majority in a single-member district. ${ }^{72}$ Second, the minority group must be politically cohesive (that is, there needs to be minority-bloc voting) ${ }^{73}$ Third, the minority must be able to prove that the

Now at War with Itself? Social Science and Voting Rights in the 2000s, 80 N.C. L. REv. 1517, 1527 (2002).

65. See Frank R. Parker, Factual Errors and Chilling Consequences: A Critique of Shaw v. Reno and Miller v. Johnson, 26 CUMB. L. REv. 527, 528 (1995-96).

66. See id.

67. See id.

68. See Allen v. State Bd. of Elections, 393 U.S. 544 (1969).

69. 515 U.S. 900 (1995). The Miller Court made numerous references to the DOJ's "maximization policy" or "maximization agenda." Id. at 909, 917-18, 921, 925-26. Whether this was driven by partisan concerns is subject to debate. See Scott E. Blissman, Navigating the Political Thicket: The Supreme Court, the Department of Justice, and the "Predominant Motive" in District Apportionment Cases After Miller v. Johnson, 5 Widener J. Pub. L. 503, $542-47$ (1996) (generally describing the DOJ's role in promoting majority-minority districts); Bernard Grofman, Would Vince Lombardi Have Been Right If He Had Said: "When It Comes to Redistricting, Race Isn't Everything, It's the Only Thing?," 14 CARDozo L. REv. 1237, 1254 (1993) (arguing that the DOJ did not pursue a partisan agenda in all cases).

70. 478 U.S. 30, 50-51 (1986).

71. 42 U.S.C. $\S 1973$ (b) (2000).

72. 478 U.S. $30,50-51$ (1986).

73. Id. 
majority votes as a bloc in such a way that it usually defeats the minority's preferred candidate. ${ }^{74}$

While the second and third prongs of the test ensure the presence of actionable vote dilution, the first and second ensure that there is a remedy, and that remedy is presumptively a majority-minority district. Given the ubiquity of racial bloc voting, ${ }^{75}$ the Gingles test essentially gave rise to a cause of action wherever there was a sufficiently large minority population to constitute a majority in a redrawn, single-member district. While the Gingles test was created in response to vote dilution within a multimember district, ${ }^{76}$ it soon was used to attack other single-member districting plans that did not, in the view of minority plaintiffs, afford them the ability to fully participate in the political system. And though courts soon moved in the direction of a multifactored "totality of the circumstances" test in such cases, Gingles, along with the DOJ's preclearance decisions, resulted in the creation of many more majority-minority districts in the 1990s.

\section{The Effect of Majority-Minority Districts on Minority Representation}

The new districts had an immediate effect on the electoral success of minority candidates. The number of African Americans in Congress increased by thirteen in 1992, which was the largest, single-year increase, in absolute numbers, in U.S. history. ${ }^{77}$ Those thirteen came from thirteen new majority-minority districts, all of which elected black candidates in both the 1992 and 1994 congressional elections. ${ }^{78}$ Overall, there was a $50 \%$ increase in the size of the Congressional Black Caucus and a 38\% increase in the size of the Hispanic Caucus as a result of redistricting after the 1990 census. ${ }^{79}$ The direct effect of majority-minority districting, then, appeared to be uniformly positive from the vantage point of minority candidates.

The rise in the number of black and Hispanic officeholders was heralded as a positive phenomenon both for minority communities and for the political system as a whole. ${ }^{80}$ Minority officeholders may be more likely than their white, liberal counterparts to play leadership roles on initiatives that help their communities. ${ }^{81}$ White Democrats may vote "the right way" on community matters, but may be less likely to take the lead. ${ }^{82}$ The

74. Id.

75. See Grofman Et al., supra note 6, at 134; Carol M. Swain, Black Faces, Black Interests: The Representation of African Americans in CONGress 209 (1993).

76. See Gingles, 478 U.S. at 46-51.

77. Richard L. Engstrom, Voting Rights Districts: Debunking the Myths, Campaigns \& Elections, Apr. 1995, at 24.

78. Id.

79. See Parker, supra note 65, at 529.

80. See SwaIN, supra note 75 , at 217 (noting that black descriptive representation may be valuable in its own right, apart from the values of substantive representation).

81. GrofMAN ET AL., supra note 6 , at 135.

82. Id. 
majority-minority districts serve as important "ports of entry" for minorities into pluralist politics. ${ }^{83}$ They are given the benefits of incumbency and allowed to earn reputations that might bring additional white crossover support. ${ }^{84}$ Thus, it is argued, the majority-minority districts, in producing additional black and Hispanic officeholders, bring benefits to the minorities they represent and to society at large.

There are, however, several drawbacks to using a strategy of majorityminority districting to improve minority political representation. First, there are demographic constraints on the use of such districts: there is a limit to the number of places one can physically and constitutionally draw additional majority-minority districts. Second, and more importantly, while majority-minority districts have undoubtedly improved the number of minority representatives, they may not have had a uniformly positive effect on the advancement of minority interests. There may be a tradeoff between descriptive representation (minority officeholders) and substantive representation (the advancement of a minority political agenda). The geographic constraints on majority-minority districts and the tradeoffs they entail are very real obstacles to increasing minority participation and are part of the dilemma of minority representation. I will look at each drawback in turn.

\section{The Geographic Limits of Majority-Minority Districts}

The first drawback to the use of majority-minority districting as a solution to the problem of minority representation is that there are not many more places to draw such districts. ${ }^{85}$ The first component of this limitation is demographic. David Butler and Bruce Cain noted early on that, because blacks are not only concentrated in Southern cities, but are also dispersed throughout the rural South, there are "severe limits on the degree to which affirmative action gerrymandering... will actually remedy minority underrepresentation in a significant way." ${ }^{86}$ In the round of redistricting following the 1990 census, majority-minority districts were drawn just about everywhere possible in the South. ${ }^{87}$

83. Id. at 135-37. Indeed, this became an important factor in the coalition districts that were formed after many of the original majority-minority districts were struck down as unconstitutional.

84. Id. at 135-37; David T. Canon et al., The Supply Side of Congressional Redistricting: Race and Strategic Politicians, 1972 - 1992, 58 J. POL. 846, 859-60 (1996) (arguing that in new majorityminority districts bi-racial coalitions arise to elect black candidates).

85. See David Butler \& Bruce Cain, Congressional Redistricting: Comparative and Theoretical Perspectives 14-15 (1992); Grofman et al., supra note 6, at 135; Swain, supra note 75, at 200-01; Kevin A. Hill, Does the Creation of Majority Black Districts Aid Republicans? An Analysis of the 1992 Congressional Elections in Eight Southern States, 57 J. POL. 384, 386 (1995); David lan Lublin, Race, Representation, and Redistricting, in CLASSIFYING BY RACE 111, 113 (Paul E. Pcterson ed., 1995).

86. BUTLER \& CAIN, supra note 85 , at 14-15.

87. See Lublin, supra note 85 , at 113 . 
A second component is constitutional. Under current Supreme Court precedent, race may not be the predominant factor in districting. ${ }^{88}$ And many of the districts created in the 1990s were subsequently struck down under Shaw and Miller. ${ }^{89}$ This new constitutional regime rules out the type of extreme gerrymanders that might make additional majority-minority districts possible.

These limits also apply with somewhat less force to so-called "coalition" districts. ${ }^{90}$ After courts struck down many of the majorityminority districts in the South under Shaw in the mid- to late-1990s, it became clear that majority-minority districts may not be necessary to elect minority candidates. ${ }^{91}$ In districts where minorities make up a substantial part of the population, but not a majority, minority voters may combine with white crossover voters to elect a minority candidate. ${ }^{92}$ However, many of the same geographic and constitutional limitations apply to the creation of coalition districts. The geographic distribution of blacks and Hispanics that limits the number of majority-minority districts also limits the number of coalition districts. Further, if race is the predominant factor used to draw coalition districts, such districts may be struck down under Shaw and Miller regardless of whether they are $50 \%, 40 \%$, or even $30 \%$ minority. ${ }^{93}$ In addition, scholars who have looked closely at coalition districts have made clear that there are many factors involved in building successful coalition districts; they do not carry with them the same guarantee of meaningful minority representation. ${ }^{94}$ Thus, there are somewhat limited prospects for improving minority representation by creating either majority-minority or coalition districts.

88. See Miller v. Johnson, 515 U.S. 900 (1995) (holding that districts may violate the Equal Protection Clause of the Constitution if race was the predominant factor in their creation); Shaw $v$. Reno, 509 U.S. 630 (1993) (holding that irregularly shaped districts can, on their face, violate the Equal Protection Clause of the Constitution).

89. For example, nine of the thirteen majority-minority congressional districts created after the 1990 census were invalidated in the latter half of the decade. See Note, The Future of MajorityMinority Districts in Light of Declining Racially Polarized Voting, 116 HARV. L. REV. 2208, 2214 n.39 (2003) (listing majority-minority districts struck down by the Supreme Court and district courts).

90. Richard Pildes has the most useful definition of a coalition district as "a district with a significant presence, though not a majority, of black voters, but that has a fifty-fifty probability of electing the preferred candidate of those black voters." Pildes, supra note 64, at 1539-40. He distinguishes coalition districts from influence districts, in which the black voters have significant, but not determinative, influence on the selection of the candidate. Id.

91. See Georgia v. Ashcroft, 539 U.S. 461 (2003); Charles S. Bullock, IIl \& Richard E. Dunn, The Demise of Racial Districting and the Future of Black Representation, 48 EMORY L.J. 1209 (1999); Grofman et al., supra note 64; Pildes, supra note 64.

92. See Bullock \& Dunn, supra note 91; Grofman et al., supra note 64.

93. See Pildes, supra note 64, at 1547-48. See also Easley v. Cromartie, 532 U.S. 234, 258 (2001) (noting that the restrictions on using race as a predominant factor in districting decisions apply to majority-minority districts and "the approximate equivalent").

94. See Grofman et al., supra note 64 , at 1411, 1423-24 (noting the importance of a variety of factors that affect whether minority voters in a district will, in fact, be able to elect a candidate of their choice, including the race of the incumbent and the racial and partisan balance in the district). 


\section{The Tradeoff Between Descriptive and Substantive Representation}

A more troubling drawback to majority-minority districts is that they may actually hinder the advancement of minority interests in a legislature. In order to create majority-minority districts, minority voters are siphoned off from surrounding districts, changing the racial composition of both: the movement of black voters into the former "bleaches," in effect, the racial composition of the latter. ${ }^{95}$ These adjoining districts may then be more likely to elect representatives with political agendas that are less sympathetic to minority interests. The net result of majority-minority districting, then, may actually be harmful to minority political interests.

A simplified example illustrates the potential dilemma. ${ }^{96}$ District $\mathrm{A}$ and District $B$ each have 100,000 voters composed of 35,000 black voters and 65,000 white voters. The voting in both districts is racially polarized. The black voters support Democrats over Republicans at a rate of $90 \%$ to $10 \%$; the white voters support Republicans over Democrats at a rate of $60 \%$ to $40 \%$. This means that in each district there are 57,500 Democrats (90\% of the 35,000 black voters $(31,500)$ plus $40 \%$ of the 65,000 white voters $(26,000)$ ) and 42,500 Republicans $(10 \%$ of the 35,000 black voters (3500) plus $60 \%$ of the 65,000 white voters $(39,000)$ ). As a result, both District A and District B send a white Democrat to the legislature.

District lines are then redrawn in order to create a majority-minority district. As a result, District $A$ is drawn to include 55,000 black voters and 45,000 white voters. This leaves District B with 15,000 black voters and 85,000 white voters. The change, as intended, has left the black voters in District $\mathrm{A}$ in position to elect a representative of their choice, a black Democrat, by a margin of 67,500 (90\% of 55,000 black voters $(49,500)$ plus $40 \%$ of 45,000 white voters $(18,000)$ ) to 32,500 . The Democrats, however, are now going to take a beating in District $\mathrm{B}$ where Republicans outnumber Democrats by 52,500 (10\% of the 15,000 black voters (1500) plus $60 \%$ of the 85,000 white voters $(51,000)$ ) to 47,500 . As a result,

95. Karlan refers to this as the "bleaching critique" of the Voting Rights Act. Pamela S. Karlan, Loss and Redemption: Voting Rights at the Turn of a Century, 50 VAND. L. REV. 291, 293 (1997). She argues, quite persuasively, that the critique oversimplifies the relationship between majority-minority districting and overall minority influence. See id. Of course, I am not using bleaching theory to critique the creation of majority-minority districts or the Voting Rights Act that produces them; instead, I use it to challenge the one person, one vote standard, which I think is at least partially responsible for the tradeoff between minority gains and Democratic Iosses. But my argument does depend, in part, on the fact that the straightforward numerical shuffling of white and African American voters is at least a partial explanation for the tradeoff.

96. The example, though greatly simplified, uses numbers that at least echo those accompanying the creation of majority-minority districts in the South. The example greatly simplifies some things, like the number of adjoining districts that are affected by creation of a majority-minority district. It aIso does not take into account other factors, like possible changes in voting behavior caused by being placed in a district with a different racial composition. For a more detailed explanation of the effects of majority-minority districts, see Karlan, supra note 95. 
District A sends a black Democrat and District B sends a white Republican to the legislature. The decision whether to support the creation of the majority-minority district turns on whether one prefers two white Democrats to one black Democrat and one white Republican. And that may depend on whether one is a Democrat or a Republican and whether one is black or white.

These potential shortcomings to the one person, one vote standard were not completely overlooked at the time of its creation. Though many opponents of the standard criticized it because it prevented states from allocating power among groups with distinct interests, a few of them noticed that those interests may be described in terms of race as well as region. For example, in the wake of Baker v. Carr, Alexander Bickel asked, "ls it irrational or otherwise forbidden so to gerrymander districts that a solid Negro or Puerto Rican vote is ensured, thus making certain that legislative bodies will contain members of these minority groups?"97 Years later, with the equiproportional mandate firmly embedded in the Constitution, he considered his question answered: "The one man, one vote rule necessarily deprives discrete groupings and interests, regional, racial, and other, of direct representation." discussed here, but he did foresee that the one person, one vote standard restrained the government's ability to allocate political power to racial minorities for more benign reasons.

In any case, this theoretical problem concerning the potential side effects of majority-minority districting resolves into at least two distinct and largely empirical questions. First, do majority-minority districts have the effect of contributing to the political success of candidates with interests antithetical to minority interests? In practical terms, this means examining whether majority-minority districting advantages white Republicans over white Democrats in adjoining districts. Second, if majority-minority districting does help Republican candidates, does the benefit of having a minority representative offset the potential disadvantage of additional Republican representatives in the legislature? To put it more bluntly, are blacks' interests better served by a few black Democrats or more white

97. Alexander M. Bickel, The Durability of Colegrove v. Green, 72 YALE L.J. 39, 43 (1962). Those who supported Baker also understood that it would limit a state's ability to numerically concentrate the voting power of racial groups; they just did not think that was a problem. As Robert McKay argued:

[T]here does not appear to be justification for special recognition in weighted votes to economic or ethnic interests. Neither labor nor management, neither dairy farming nor shipping, neither racial nor religious minorities should be entitled as such to a weighted voice in the legislative forum. To do so is to tilt the democratic process dangerously and impermissibly.

Robert B. McKay, Political Thickets and Crazy Quilts: Reapportionment and Equal Protection, 61 Mich. L. REV. 645, 696-97 (1963).

98. Alexander M. Bickel, The New Supreme Court: Prospects and Problems, 45 TuL. L. REv. 229, 242 (1971). 
Democrats? If majority-minority districting really does advantage minority candidates only at the cost of losing Democrats in the legislature, minority political strategists are currently forced to make this political choice.

The first question, about the effect of majority-minority districts on the political fortunes of Republicans, may be examined from several angles. For example, if Republicans are advantaged, we should see a couple of things happening with respect to majority-minority districts. ${ }^{99}$ First, and most directly, majority-minority districts should have the perverse effect of increasing the number of Republicans and decreasing the number of Democrats in the legislature. Second, there should be a somewhat unorthodox political alliance formed between civil-rights groups and Republicans pushing for such districts.

\section{i. Majority-Minority Districts Benefit the Republican Party: Theoretical and Empirical Evidence}

There was strong evidence that majority-minority districts would help Republicans even before much majority-minority districting had been done. Several authors discussed the theoretical likelihood that concentration gerrymandering would have a perverse effect upon the representation of the concentrated group's political agenda. ${ }^{100}$ Others made more pointed predictions that majority-minority districts would lead to the defeat of white Democrats by white Republicans and thus produce more conservative legislative majorities. ${ }^{101}$ One early study of South Carolina redistricting plans found a significant correlation between the number of majorityminority districts and the expected number of Republicans elected. ${ }^{102}$ The theoretical models, then, seem to predict that racial gerrymandering ends up helping Republicans.

Such predictions have also been supported by a range of empirical studies. A large number of studies examine the effect of majority-minority districts on the 1992 and 1994 congressional elections. ${ }^{103}$ Bob Benenson argued, on the heels of the 1992 election, that three white Democratic

99. See Kenneth W. Shotts, The Effect of Majority-Minority Mandates on Partisan Gerrymandering, 45 AM. J. PoL. Scl. 120 (2001). Shotts writes of a third effect, that such districts will decrease substantive representation of minority voters' interests. $I d$. at 120.1 deal with this effect later in the Article as part of my second empirical question.

100. See, e.g., Bruce E. Cain, The Reapportionment Puzzle 166-71 (1984); Robert S. Erikson, Malapportionment, Gerrymandering, and Party Fortunes in Congressional Elections, 66 АM. PoL. SCI. REV. 1234 (1972).

101. See, e.g., David Lublin, The Paradox of Representation 119 (1997); Swain, supra note 75 at 205-06; Abigall. M. Thernstrom, Whose Votes Count? Affirmative ACtion and Minority Voting Rights 234 (1987).

102. See Kimball Brace et al., Does Redistricting Aimed to Help Blacks Necessarily Help Republicans?, 49 J. PoL. 69 (1987).

103. For some brief discussions of those studies, see David T. Canon, Race, Redistricting, and Representation: The Unintended Consequences of Black Majority Districts 74 (1999); and Shotts, supra note 99, at 120. 
incumbents lost to Republicans as a result of racial redistricting. ${ }^{104}$ Kevin Hill later put the number at four. ${ }^{105}$ Carol Swain's number is five ${ }^{106}$ and David Lublin maintains that five or six white Democrats were defeated as a result of racial redistricting. ${ }^{107}$ When the 1992 and 1994 elections are taken as a group, Lublin argues, the number rises to eleven. ${ }^{108}$ Some scholars have also looked at the effect of racial redistricting on state legislative elections and found a similar rise in Republican fortunes. ${ }^{109}$ So, while there is some disagreement as to the exact extent of the impact, the empirical evidence appears to support the point that racial gerrymandering of this sort advantages Republicans over Democrats. ${ }^{110}$

The claim that racial gerrymandering leads to Republican gains at the expense of Democrats is not uncontroversial. Some commentators, after looking at most of the studies discussed above as well as others, concluded that "[t]he true electoral effect of racial redistricting remains unclear." There are both theoretical and empirical reasons for the lack of clarity on the question. Some scholars have argued that majority-minority districts do not necessarily lead to Republican gains. ${ }^{112}$ Instead, such a relationship depends upon several other factors, such as whether the majority-minority districts are really supermajority districts, ${ }^{113}$ whether there is Republican

104. See Bob Benenson, Redistricting: GOP's Dreams of a Comeback via the New Map Dissolve, 50 CONG. Q. WKLY. 3580-81 (1992).

105. See Hill, supra note 85 , at 399 . Hill also found that other faetors helped Republicans in the 1992 elections. By his tally, seventeen Republican districts became less competitive and eleven Democratic districts became more competitive as a result of majority-minority districting. $/ d$. at 387 .

106. See Carol M. Swain, The Future of Black Representation, AM. ProsPECT, Fall 1995, at 78.

107. Lublin, supra note 85 , at 112.

108. Lublin, supra note 85, at 114; David Lublin \& D. Stephen Voss, The Partisan Impact of Voting Rights Law: A Reply to Pamela S. Karlan, 50 SrAN. L. Rev. 765, 772 (1998).

109. See Lisa Handley et al., Electing Minority-Preferred Candidates to Legislative Office: The Relationship Between Minority Percentages in Districts and the Election of Minority-Preferred Candidates, in RACE AND REDistricting IN THE I990s 11, 38 (Bemard Grofman ed., 1998) (finding that Democratic losses in the first round of redistricting after the 1990 census was probably the result of an increase in the number of overwhelmingly white districts); David Lublin \& D. Stephen Voss, Racial Redistricting and Realignment in Southern State Legislatures, 44 AM. J. POL. SCl. 792 (2000) (examining all state legislative elections in the South from 1990 to 1998 and finding that racial redistricting harmed Democrats in every state and cost them control of at least two state houses). The importance of state legislative elections should not be underestimated. State legislatures, in addition to making important policy decisions that affect minority interests, are also in charge of congressional redistricting, and thus may play an important role in determining the effect of majority-minority congressional districts on adjoining districts.

110. In addition to those scholars already cited, see also STEPHan Thernstrom \& AbigalL Thernstrom, America in Black and White 483 (1997); Charles S. Bullock, Affirmative Action Districts: In Whose Faces Will They Blow Up?, Campaigns \& Elections, Apr. 1995, at 22.

111. Lublin \& Voss, supra note 109, at 792.

112. See Engstrom, supra note 77, at 24; Grofman, supra note 69, at 1251-52; John R. Petrocik \& Scott W. Desposato, The Partisan Consequences of Majority-Minority Redistricting in the South, 1992 and 1994, 60 J. PoL. 613, 629-30 (1998); Shotts, supra note 99, at 130-31.

113. See Shotts, supra note 99 , at 130-31. 
strength close to the majority-minority districts, ${ }^{114}$ and who does the redistricting-Republicans or Democrats. ${ }^{115}$ Indeed, this final factor seems to be very important, as a Democratically controlled state legislature can often draw majority-minority districts in such a way that does not affect the status of Democratic incumbents in surrounding districts. In addition, while some acknowledge that racial gerrymandering played a role in the 1992 and 1994 congressional elections, it may be that the general realignment toward the Republicans played an even greater role in Democratic losses. ${ }^{116}$ The same may be said for Democratic losses in state legislatures as well. ${ }^{117}$

But this is not to say that majority-minority districting did not, overall, help Republicans in both federal and state races. To be sure, there was an important surge as white voters increasingly voted Republican, and there were instances where Democratic state legislatures were able to draw majority-minority districts in ways that preserved Democratic seats. But, these issues aside, the weight of the evidence supports the proposition that such districts did help Republicans on both the federal and state levels in the 1990s. Thus, majority-minority districts do seem to have the perverse effect of increasing the number of Republicans and decreasing the number of Democrats in the legislature.

Now we turn to the related question of whether civil-rights groups and Republicans formed a relatively unorthodox political alliance in pushing for such districts. Republicans might push for majority-minority districts for several reasons. Most obviously, if such districts actually benefit their party on a larger scale, it is in their interest to have more of them. ${ }^{118}$ Moreover, minority candidates coming out of majority-minority districts are likely to be well to the left of the political mainstream, thus taking the Democratic party further from the center. ${ }^{119}$ This may also have the effect of splitting the Democratic party. ${ }^{120}$ And, finally, to the extent that majority-minority districts reinforce race-related voting, and Republicans

114. See Brace et al., supra note 102, at 183; Grofman, supra note 69, at 1251-52.

115. See Brace et al., supra note 102, at 183; Grofman, supra note 69, at 1251-52; Shotts, supra note 99 , at $130-31$.

116. See Engstrom, supra note 77, at 24 (arguing that Republican gained seats in the nine southern states with new majority-minority districts at the same rate as they gained seats in the other forty-one states); Lani Guinier, Don't Scapegoat the Gerrymander, N.Y. TIMES, Jan. 8, I995, § 6 (Magazine), at 36 (listing scveral other reasons for Democratie losses in the 1994 congressional clections and arguing that losses in the South were no greater than elsewhere); Karlan, supra note 95, at 304-07 (1997) (noting that there was a longtime drop of the Democratic share of the white vote in the South); Petrocik \& Desposato, supra note 112, at 630 (arguing that the shift in political tides to the Republican party was the necessary ingredient in Democratic congressional losses).

117. See Lublin \& Voss, supra note 108, at 801-03 (arguing that while racial redistricting cost the Demoerats at the state legislative level, Republican realignment had a greater impact).

118. See Swain, supra note 75, at 205; Paul E. Peterson, A Politically Correct Solution to Racial Classification, in Classifying by RaCe 3, 11 (Paul E. Peterson ed., 1995).

119. See Peterson, supra note 118 , at 12.

120. See id. at 13. 
benefit from racial conflict, that might also help their party. ${ }^{121}$ Thus, one might expect Republicans, though they may philosophically oppose majority-minority districts as affirmative action for black politicians, to work behind the scenes to support such districts. Conversely, one might expcct Democrats to support the districts in theory but work to undermine them. ${ }^{122}$ And that appears to be exactly what happens.

There was sometimes tacit, sometimes overt, collusion between representatives of the minority community and Republicans to maximize majority-minority districts. ${ }^{123}$ In the early I990s, the Republican National Committee pushed for more black and Hispanic districts as part of a strategy to win additional seats in the House. ${ }^{124}$ The Committee also made a concerted effort to win control of state legislatures using the same strategy. ${ }^{125}$ Some critics claimed that the DOJ was enforcing the Voting Rights Act as part of a Republican conspiracy to "whiten" surrounding districts, but there does not seem to be any evidence of illegitimate influence. ${ }^{126}$ That is, there does not seem to be evidence that the Republican party manipulated the DOJ's prcclearance decisions or other litigation decisions in order to win additional seats. Indeed, they did not need to - the party usually benefited from the DOJ's routine enforcement of the Act.

Democrats were not immune from this sort of hypocrisy. In many cases, they would seek to reduce the number of majority-minority districts. In Georgia, for example, Democrats sought to reduce the number of safe minority districts in the state senate in order to improve the party's overall chances. ${ }^{127}$ Democrats did something similar in New Jersey. ${ }^{128}$ Thus both parties act as though there is a very real political tradeoff to be made in the case of majority-minority districts. ${ }^{129}$

In sum, there is strong evidence that Republicans are advantaged by the creation of majority-minority districts. There is evidence that such districts contributed to some of the Republican gains on the federal and state level in the 1990s. The Republican Party, despite its philosophical objections to racial redistricting, clearly thought there was something to be gained by it. And Democrats, despite being generally favorable toward improving black representation, sought to undermine the creation of

\footnotetext{
121. See id. at 12-13.

122. See Canon et al., supra note 84 , at 848 n.4.

123. Charles Cameron et al., Do Majority-Minority Districts Maximize Substantive Black Representation in Congress?, 90 AM. Pol. SCl. Rev. 794, 810 (1996).

124. See SwaIN, supra note 75, at 205; Peterson, supra note 118, at 10-11.

125. Grofman, supra note 69 , at 1249-51.

126. See id. at 1253-56.

127. See Georgia v. Ashcroft, 539 U.S. 461 (2003).

128. See Page v. Bartels, 248 F.3d 175 (3d Cir. 2001).

129. For a brief discussion of this phenomena, see Nathaniel Persily, Suing the Government in Hopes of Controlling It: The Evolving Justifications for Judicial Involvement in Politics, $5 \mathrm{U}$. PA. J. Const. L. 607, 610-11 (2003).
} 
additional majority-minority districts. So, given that additional minority representatives come at the cost of a shift from Democratic to Republican representatives, the question remains: Are majority-minority districts, in the end, a net advantage or disadvantage in the quest for meaningful minority representation?

The answer to this question may turn on what one means by "representation." It is useful here to look at Hannah Pitkin's analysis of the term. ${ }^{130}$ Pitkin distinguishes descriptive representation from substantive representation. ${ }^{131}$ Descriptive representation occurs when there is a correspondence between the representatives' characteristics and those of their constituents. ${ }^{132}$ In this case, that would mean that a black officeholder descriptively represents black constituents. But, as Bernard Grofman notes, "Being typical may be roughly synonymous with being representative, but it is neither a sufficient nor a necessary condition for being an effective representative." 133 By "effective" representation, Grofman means substantive representation, which occurs when there is a correspondence of the representatives' goals with the goals of their constituents. ${ }^{134}$

\section{ii. The Tradeoff Between Descriptive and Substantive Representation}

Once we are clear on what we mean by representation, the dilemma can be recast. Majority-minority districts certainly increase descriptive representation: the addition of majority-black districts results in a net increase in the number of black representatives in the legislature. If the advancement of minority interests can be measured by the number of minority officeholders, then majority-minority districts have been successful in increasing minority representation. The issue, however, is whether such districts, by helping Republicans in remaining districts, actually have the overall effect of decreasing substantive representation. Even though there may be more black Democrats, there may be fewer Democrats overall, leading to the question of whether majority-minority districting represents a tradeoff between descriptive and substantive representation. ${ }^{135}$

130. Hanna Fenichel Pitkin, The Concept of Representation (1967). Pitkin's distinction is also discussed in this context by SwaIN, supra note 75, at 5-13.

131. PirkIN, supra note 130 , at 60-91, 114. The distinction was recently embraced by the Supreme Court as part of their reasoning in Georgia v. Ashcroft, 539 U.S. 461 (2003).

132. See PITKIN, supra note 130 , at $60-91$.

133. Bernard Grofman, Should Representatives Be Typical of Their Constituents?, in Representation and Redistricting Issues 97, 99 (Bernard Grofman et al. eds., 1982).

134. Id. at 98 .

135. See Cameron et al., supra note 123 , at 794 . The tradeoff can also be described as a tradeoff between control and influence, or between control of a district and control of a legislature (thanks to Nate Persily on this point). Or, to rephrase in terms of Pamela Karlan's newer taxonomy of voting rights, it involves a tradeoff between aggregation and governance. See Karlan, The Rights to Vote, supra note 5, at 1709-20. Regardless of how it is described, however, this tradeoff is ultimately unavoidable. 
The question of this potential tradeoff, in turn, depends upon whether the loss of white Democrats matters to black political interests. Most scholars seem to think that it does. Although there are many different ways of rating a representative's support of black interests, most scholars analyze votes on civil rights and redistributive social-welfare programs. ${ }^{136}$ Unsurprisingly, Democrats are almost always more supportive of such measures than Republicans, ${ }^{137}$ which seems to indicate that an overall loss of white Democrats matters to black politieal interests. ${ }^{138}$ Removing minority voters from the districts surrounding a new majority-minority district may also affect how sympathetic white incumbents are to black interests. For example, one study found that white incumbents who lost black voters during redistricting for the 1992 election cycle became less sensitive to black concerns. ${ }^{139}$ So, at some level, majority-minority districting does entail a tradeoff between descriptive and substantive representation.

This tradeoff forces advocates for minority representation to make a choice between descriptive and substantive representation. That is not to say that the two never go hand in hand. Minority officeholders almost always vote in favor of legislation important to minority interests. Thus, the question remains whether the benefit of having a minority representative offsets the potential disadvantage of additional Republican representatives in the legislature. Are black interests better served by a few black Democrats or more white Democrats? There is evidence, for example, that while white Democrats vote in favor of legislation of importance to the African American community, they are less likely than black officeholders to take the lead and initiate such legislation. ${ }^{140}$ But this question is not directly relevant to our inquiry, for so long as majority-minority districting involves some representational costs, minority-voting-rights advocates are forced to make a choice.

136. Figuring out what blacks' interests are is somewhat difficult. Carol Swain divides them into objective and subjective interests. See SWAIN, supra note 75 , at 6 . Objective interests are those based on observable phenomcna, such as income, employment status, educational opportunity, and health care. See id. at 7-10. Subjective interests are based on the group's perception of its interest, and, while often related to objective interests, does not have to be identical to them See id. at 6,10-11. She also takes into account the position of organized interest groups, such as the National Association for the Advancement of Colored People, the National Urban League, and the Congressional Black Caucus. See id. at 11-13.

137. See id. at 13-19 (analyzing congressional support of black interests based on scales devised by the Committee on Political Education, the Leadership Conference on Civil Rights, and herself).

138. See id. at $15,19$.

139. See L. Marvin Overby \& Kenneth M. Cosgrove, Unintended Consequences? Racial Redistricting and the Representation of Minority Interests, 58 J. POL. 540 (1996).

140. Vincent Di Lorenzo, Legislative Heart and Phase Transitions: An Exploratory Study of Congress and Minority Interests, 38 WM. \& MARY L. REv. 1729 (1997). 


\section{iii. Principles that Limit the Effectiveness of Majority-Minority Districts}

Why, exactly, are minority-voting-rights advocates forced to make such a choice? In other words, what are the conditions that make such a choice necessary? Some are related to the enduring existence of racial bloc voting. Some are the result of the majoritarian structure of most of our democratic institutions. And some may be the result of existing voting rights law. I will take an example of each of these conditions in turn.

One reason why majority-minority districts force such a choice, and why many suggest that majority-minority districts are a solution to the lack of descriptive representation, is the presence of racial bloc voting. Black voters overwhelmingly vote Democratic and vote for black Democrats when given a choice; white voters, in increasing numbers, vote Republican and vote for white Republicans. ${ }^{141}$ There is a deep and widening racial divide in America with regard to public opinion on a broad range of issues. ${ }^{142}$ And despite some views to the contrary, ${ }^{143}$ redistricting, and even voting rights law generally, have very little effect on this state of affairs. ${ }^{144}$ Even the advent of successful coalition districts-and the possibility that they signal a decline in racial bloc voting - does nothing to eliminate the representation tradeoff. ${ }^{145}$ So while one could try to avoid the choice by eliminating racial bloc voting, voting rights law is not a very good tool for such

141. See Grofman et al., supra note 64, at 1400-01. Indeed, in the history of the United States, only six black candidates have won elections in districts with white, non-Hispanic majorities. See Peterson, supra note 118 , at 112. And most blaek candidates who have won in white congressional districts did so under peculiar circumstances. See David Lublin, Racial Redistricting and AfricanAmerican Representation: A Critique of "Do Majority-Minority Districts Maximize Substantive Black Representation in Congress?," 93 AM. Pol. SCl. Rev. 183, 184 (1999).

142. See Donald R. Kinder \& Lynn M. Sanders, Divided by Color: Racial Politics and DEMOCRATIC IDEALS 33-34 (1996). Some commentators have recently noted that majority-minority districts may not be as necessary in part because racial bloc voting is declining. See, e.g., Pildes, supra note 64 , at 1529-39; Note, supra note 89 , at 2219. But it is unclear whether racial bloc voting is actually declining or whether social scientists in the 1980 s and early 1990 s overestimated the percentage of minorities necessary to elect a candidate of their choice. See Pildes, supra note 64, at 1532 n.39. In any case, I think it is safe to say that there is still a large racial divide on issues and that racial bloc voting, though it may be declining in some regions, remains significant.

143. The Thernstroms have been particularly adamant on this point. See, e.g., Thernstrom \& THERNSTROM, supra note 110 , at $489-92$ (arguing that using race to draw district lines perpetuates racial division); THERNSTROM, supra note 101, at 237-38; Abigail Thernstrom, "Voting Rights" Trap, New Republic, Sept. 2, I985, at 21, 23 (1985). The Supreme Court put forth this theory when Justice O'Connor's majority opinion in Shaw v. Reno likened such districting to "political apartheid." 509 U.S. 630,647 (1993). Justice O'Connor continued:

It reinforces the perception that members of the same racial group-regardless of their age, education, economic status, or the community in which they live-think alike, share the same political interests, and will prefer the same candidates at the polls. ... By perpetuating such notions, a racial gerrymander may exacerbate the very patterns of racial bloc voting that majority-minority districting is sometimes said to counteract. Id. at 647-48.

144. See Parker, supra note 47 , at 533

I45. See Note, supra note 89 , at 2228. 
a change. And, in any case, if one could eliminate racial bloc voting, one would not need majority-minority districts to begin with.

Some of the conditions for the choice come out of the basic structure of our winner-take-all, majoritarian democracy. For this reason, advocates like Lani Guinier have proposed positional voting systems like cumulative voting to get around the problem. ${ }^{146}$ In such a system, minority voters are able, by bullet voting in the case of cumulative voting, to ensure that the representative of their choice is elected.$^{147}$ It is an elegant solution to the problem, ${ }^{148}$ but one that, thus far, has not caught on despite some sporadic local experimentation. Thus, the desire to maintain a majoritarian as opposed to a proportional election structure forces the tradeoff and the choice to be made.

Finally, voting-rights law poses some of the constraints that are responsible for the representation dilemma facing minority-voting-rights advocates. The Shaw line of cases, for example, places an upper constraint on the number of majority-minority districts that may be constitutionally drawn. ${ }^{149}$ Freed from Shaw's prohibitions, voting-rights advocates might be able to squeeze a few more districts out of the next round of redistricting. But the advocates' success would be limited by another constitutional requirement, the one person, one vote rule, which plays an even more significant role in forcing minority voters to choose between descriptive and substantive representation.

Throughout this discussion, we have been (correctly) assuming that the voting districts we are talking about are required to have equal populations. The Supreme Court has read Article I to require congressional districts within the same state to have almost perfectly equal populations. ${ }^{150}$ State and local districts get a little more leeway but are generally expected to have no more than a $10 \%$ maximum deviation, ${ }^{151}$ a few percentage points more if suitably justified. ${ }^{152}$ These constitutional rules make the creation of majority-minority districts a zero-sum game: increasing the percentage of minority voters in one district inevitably means reducing it in another. The one person, one vote requirements are a necessary element in the representational dilemma faced by advocates of minority voting rights.

146. Lani Guinier, The Representation of Minority Interests: The Question of Single-Member Districts, 14 Cardozo L. Rev. 1135, 1156 (1993).

147. More specifically, in a cumulative voting system, each voter is allotted as many votes as there are open seats. Voters may distribute their votes as they see fit, either clumping their votes for one candidate, called bullet voting, or dispersing their votes among several candidates. The candidates receiving the most votes win.

148. Its elegance stems from, among other things, the fact that voters place or organize themselves into groups, instead of bcing placed into a group by those drawing district lines.

149. See Shaw v. Reno, 509 U.S. 630 (1993)

150. See supra note 44.

151. See supra note 42 and accompanying text.

152. See supra note 43 and accompanying text. 
Perhaps, then, we should examine those requirements a little more closely, with an eye to improving the lot of minority voters.

II

The One Person, One Vote Standard

A. The Popular, "Objective" Standard

On its face, the one person, one vote standard has a lot going for it. It is a catchy slogan, phrased in a way that makes opposition seem ridiculous. Who, for example, would advocate something like one person, two votes? It appeals to our sometimes contrary impulses of rugged individualism ("one person") and civic mindedness (voting). And, best of all, it appears to be absolutely neutral with respect to geography and politics: every voter, no matter where she lives or what she believes, gets to have her vote weighted equally. But first impressions aside, the standard does not come with a very impressive theoretical resume. And its supporters grossly overstate its claim to neutrality. ${ }^{153}$

Despite the fact that many fundamental American institutions (the Senate, for example) do not conform to it, the one person, one vote standard enjoys tremendous appeal among the public, politicians, and scholars. ${ }^{154}$ The public has accepted it wholeheartedly. ${ }^{155}$ Politicians, while initially reluctant to embrace a standard that might dispossess them of their power, soon came to accept $\mathrm{it}^{156}$ (or, in many cases, were soon replaced by politicians from the newly drawn districts). ${ }^{157}$ And scholars, with much weeping and gnashing of teeth, ${ }^{158}$ also came to positions that were roughly in accord with the standard. Some question the necessity of requiring

153. See Hayden, supra note 4, at 226-28 (cataloging the shortcomings of the standard's claim to neutrality).

154. See id. at 222-25. This is in marked contrast to the popular response to some of the Warren Court's other civil-rights holdings. See lssacharoff, supra note 40 , at $1657 \mathrm{n} .72$ (stating that "the appeal of individual equality in the political process proved so strong that these decisions did not spark an outcry similar to that arising in response to the Court's forays into the civil rights and criminal justice areas"); Pamela S. Karlan, The Fire Next Time: Reapportionment After the 2000 Census, 50 StAN. L. REv. 731, 741 (1998) (claiming that, unlike some of the Warren Court's other holdings, "one person, one vote has occasioned no backlash and seems wildly popular across the political spectrum"); Robert B. McKay, Reapportionment: Success Story of the Warren Court, 67 Mich. L. REv. 223, 224-25 (1968) (noting that the decisions were more easily accomplished than those involving race relations, the First Amendment, and criminal justice).

155. See Guinier \& Karlan, supra note 45, at 207 ("Ask the average person on the street what democracy means and she is likely to reply 'majority rule.' Ask her what political equality means and she is likely to reply 'one person, one vote."').

156. See id. at 211 (noting that, while in the early 1960s forty-eight of the fifty states had legislatures with district variances of more than $15 \%$, by the early 1970 s only fourteen states had such large variances).

157. See John Hart Ely, Democracy and Distrust 121 (1980)

158. See Robert J. Pushaw, Jr., Bush v. Gore: Looking at Baker v. Carr in a Conservative Mirror, 18 Const. Comment. 359, 379-82 (2001) (documenting early opposition to the malapportionment decisions). 
perfect adherence to the standard in a world of imperfect demographic information. ${ }^{159}$ Some focus on the related problem of being able to bootstrap almost any potential challenge to a redistricting plan on the back of a one person, one vote challenge. ${ }^{160}$ But few have directly questioned the wisdom of the standard or have taken the time to explore its foundations. Instead, critics of the standard oftentimes simply claim that there are few, if any, compelling justifications for the rule. ${ }^{161}$

This is not to say that there are no arguments in favor of the one person, one vote standard. The most concrete justification for the standard is historical: it was necessary to break the stranglehold that state legislators had over the redistricting process. Voters who lived in growing urban districts were numerically underrepresented in Congress and state legislatures and, consequently, received less federal and state attention. ${ }^{162}$ The state legislators in charge of the redistricting process were not about to redistrict themselves out of office, and, hence, there was no political solution in sight. Given that outlook (and sixty years of increasingly disproportionate district populations), the judiciary stepped in, found the issue to be justiciable, and applied the equiproportional standard. The one person, one vote standard, then, was part of a solution to a very real problem of political representation.

There is little to suggest, however, that perfectly equal voting districts were a necessary part of that solution. The differences in voting power challenged in Baker and Reynolds were on the order of twenty and fortyone to one. ${ }^{163}$ Such large disparities, as discussed above, had a real effect

159. See Hayden, supra note 4, at 232-33 (discussing various problems with demographic data and criticisms of a precisely applied equiproportional rule); see also Issacharoff, supra note 40, at 1654 .

160. See Karcher v. Daggett, 462 U.S. 725, 778 (1983) (White, J., dissenting) ("More than a decade's experience with Kirkpatrick demonstrates that insistence on precise numerical equality only invites those who lost in the political arena to refight their battles in federal court."); Karlan, supra note 154 , at 735 ("While the law requires that district populations be as equal as practicable, nobody really sues because the congressional district to which he has been assigned has 527,472 voters while another district has only 523,798." (footnote omitted)); Karlan, The Rights To Vote: Some Pessimism About Formalism, supra note 5, at 1730 (describing one person, one vote claims as "vehicle lawsuits" that are "empty of any real content but pregnant with the possibility of persuading a court to adopt a favorable new plan").

161. See, e.g., Robert H. Bork, The Tempting of America 87 (1990) (criticizing the redistricting decisions on the basis that the "Warren majority's new constitutional doctrine was supported by nothing"); ELY, supra note 157, at 121 (famously noting that while the one person, one vote standard "is certainly administrable ... the more troublesome question is what else it has to recommend it").

162. See BAKER, supra note 25 , at $48-51$ (describing examples of state inaction on urban problems); HACKER, supra note 28, at 95-99 (discussing the impact of malapportioned seats on congressional decisions); McKaY, supra note 25, at 56-57 (describing instances where state legislatures in Illinois, New York, and Tennessee acted in ways that disadvantaged those in the states' more populous areas).

163. See Reynolds v. Sims, 377 U.S. 533, 545 (1964); Baker v. Carr, 369 U.S. 186, 245 (1962) (Douglas, J., concurring). 
on political outcomes. ${ }^{164}$ But, given the size of the disparities and the thin theoretical arguments for numerically equivalent districts, this may have been a case where "the Court wielding a sledgehammer helps, while a judge applying a scalpel does only harm."165 The sledgehammer could have taken the form of a blanket pronouncement that such large deviations in district populations were not constitutionally tolerable. ${ }^{166}$ Instead, the Court eventually decided to dramatically narrow the range of acceptable numerical deviation and, in the case of congressional districting, to eliminate it almost entirely.

The second, more sustaining justification offered for the one person, one vote standard is its "neutrality" or "objectivity." 167 In one sense, we view the standard as objective because of its relationship to a majoritarian system of democracy. ${ }^{168}$ Deviations in relative district populations translate quite readily into deviations from the principles of majority rulerepresentatives elected by a minority of voters may make up a majority of the governing body. The larger the deviations, the smaller the potentially controlling minority. ${ }^{169}$ Enforcement of the equiproportional standard is necessary to maintain majority rule. ${ }^{170}$ This assumes, of course, that we all

164. See supra note 45 and accompanying text.

165. Abner J. Mikva, David C. Baum Memorial Lecture: Justice Brennan and the Political Process: Assessing the Legacy of Baker v. Carr, 1995 U. ILL. L. Rev. 683, 697; accord Martin Shapiro, Gerrymandering, Unfairness, and the Supreme Court, 33 UCLA L. REv. 227, 227-29 (1985).

166. Luis Fuentes-Rohwer points out that the early reapportionment cases provided (correctly, in his view) just such a standard; only later did the Court become more inflexible. See Luis FuentesRohwer, Baker's Promise, Equal Protection, and the Modern Redistricting Revolution: A Plea for Rationality, 80 N.C. L. REv. I353 (2002).

167. See, e.g., Karlan, supra note 154, at 741 (describing the one person, one vote standard as the "paradigmatic 'objective' rule" that "seem[s] to avoid the invocation of a contestable political philosophy"); 1ssacharoff, supra note 40, at 1648 (noting that the Court in the 1960s considered the one person, one vote standard to be an objective, easily managed basis for political equality).

168. See Guy-Uriel E. Charles, Constitutional Pluralism and Democratic Politics: Reflections on the Interpretive Approach of Baker v. Carr, 80 N.C. L. REv. 1103, 1147 (2002) (discussing the one person, one vote standard as a "core requirement of democracy" reflected in the reapportionment decisions).

169. Take, for example, a hypothetical state with 100,000 people divided into ten districts. If six of the districts have 8000 people each and the other four have 13,000, the total deviation from the ideal district size is $50 \%$, and $48 \%$ of the state's population can, theoretically, elect a eontrolling majority in the statehouse. If, on the other hand, the six smaller districts have 6000 people each, and the other four distriets have 16,000 , the total deviation from the ideal district size is $100 \%$, and $36 \%$ of the state's population can elect a controlling majority in the statehouse. Of course, the relationship between the total deviation and the size of a possible controlling majority not only depends upon the total deviation, which only takes account of the largest and smallest district, but the population of the districts in between as well.

170. Many of the Court's early decisions in the area actually focused on this aspect of the reapportionment claims. See, e.g., Reynolds v. Sims, 377 U.S. 533, 545 (1964) ("Under the existing provisions, applying 1960 census figures, only $25.1 \%$ of the State's total population resided in districts represented by a majority of the members of the Senate, and only $25.7 \%$ lived in counties whieh could elect a majority of the members of the House of Representatives."). McKay discusses the common use of this measure of quantitative dilution, known as the Dauer-Kelsay measure of representativeness and its use by the Supreme Court. MCKAY, supra note 25, at 43-45. McKay also lists the minimum 
agree that some sort of pure majority rule is desirable, which, descriptively anyway, is off the mark. It also assumes that by "majority" we mean a majority of the actual people, not the interests into which they may be grouped.

The standard is also "objective" in the sense that it allows the courts to avoid making subjective decisions. The Court's initial reluctance to consider malapportionment claims stemmed, in large part, from the fear that courts would be put in the position of making political judgments best reserved to legislatures. ${ }^{177}$ Once the Court overcame its initial reluctance and stepped into the political thicket, it was still wary of the potential that judges would interject their own political judgments into the process-that they would, in a sense, become quasi-dictators and usurp control of the political system from elected representatives. ${ }^{172}$ The one person, one vote standard seemed to take such discretion out of their hands. This is what is meant by those touting the fact that the standard is "easily managed."173 Its strict application means that judges could not impose their own subjective beliefs about the proper allocation of political power.

While the one person, one vote standard is certainly manageable and in that sense objective, such objectivity does not get us very far. First, if the only goal is to remove judicial discretion from the equation, the equiproportional standard is just one of a number of ways to determine proper relative district population. ${ }^{174}$ For example, judges could randomize relative district populations or accept any population within a certain, perhaps historically determined, range. In either case, judicial discretion and the ability to determine political outcomes is eliminated. Second, the precise application of the one person, one vote standard actually increases the likelihood that judges and not legislators will make redistricting decisions. Quantitative vote-dilution claims are often just a vehicle for an aggrieved party to attack an otherwise unfavorable districting plan. ${ }^{175}$ Once the plan is in front of a court, everything is in play since there are countless ways to slice the population into equally sized districts. For this reason, commentators like Richard Hasen, among others, argue that manageability

percentage of the population that can elect a majority of representatives in each of the fifty states' legislative bodies. Id.

171. See Colegrove v. Green, 328 U.S. 549, 556 (1946).

172. See Reynolds v. Sims, 377 U.S. 533, 620 (1964) (Harlan, J., dissenting) (arguing that courts were incompetent to make such dccisions); see also Richard L. Hascn, The Benefits of "Judicially Unmanageable" Standards in Election Cases Under the Equal Protection Clause, 80 N.C. L. REv. $1469,1475-80$ (2002) (detailing the judicial search for manageable standards in early reapportionment decisions).

173. See, e.g., Issacharoff, supra note 40, at 1648; Karlan, supra note 154, at 741 .

174. See Hayden, supra note 4 , at $227-28$

175. See Karcher v. Daggett, 462 U.S. 725,778 (1983) (White, J., dissenting); Karlan, supra note 154, at 735; Karlan, The Rights To Vote, supra note 5, at 1730. 
is actually a vice that gets courts in the habit of intervening in political disputes. ${ }^{176}$

\section{B. The Lack of Objectivity}

Upon closer examination, the claim of objectivity is even weaker than it seems. ${ }^{177}$ In fact, when one looks at voting at its most fundamental level-that is, as the way that voters reveal their preferences-it is difficult to see how the standard can be justified as neutral or objective at all. Voting involves revealing political preferences; counting votes involves aggregating those preferences. So figuring out how much weight should be given to a person's vote means figuring out how much weight should be given to each person's preferences. The one person, one vote standard assigns equal weights to all voter preferences. But there is no ready method of checking whether this accurately reflects the strength of those preferences. With no scale for weighing preferences, one needs to weigh them in relation to each other, which means that one needs to make interpersonal utility comparisons.

In discussing the relationship between preference strength and the weight of votes, I am making what is mainly a descriptive point. ${ }^{178}$ There are many reasons why one would not want to directly tie the weight of one's vote to the strength of her interest in an election. ${ }^{179}$ That said, there are many instances in which one's right to vote depends upon the strength of one's preferences. ${ }^{180}$ When it comes to the right to cast a ballot, controversy often revolves around which people have sufficient interest in the outcome of an election to allow them to vote. For example, the early property-holding requirements and taxpaying requirements were both partially justified on the basis that only those with a sufficient economic stake in an

176. See HASEN, supra note 4, at 47-72.

177. There may be other reasons for thinking the one person, one vote standard is not quite as neutral as it appears. A judge may further her substantive political goals by resolving some of the remaining doctrinal ambiguities in a way that favors particular outcomes. For example, there is not complete agreement with respect to the relevant apportionment base (the denominator in the equation). Is it population, voting age population, citizen voting age population, registered voters, or, if even possible, actual voters? The choice is not without consequence, and may allow the judiciary quite a bit of discretion. For discussion of this issue, see Hayden, supra note 4, at 231-32; Taren StinebricknerKauffman, Counting Matters: Prison Inmates, Population Bases, and "One Person, One Vote," 11 VA. J. Soc. Pol'y \& L. 229 (2004); Rosanna M. Taormina, Comment, Defying One-Person, One-Vote: Prisoners and the "Usual Residence" Principle, 152 U. PA. L. REv. 431 (2003).

178. Hayden, supra note 4 , at 248-49.

179. We would not want to undervalue the votes of minority voters who care less about the outcome of an election because they have been excluded from the political process for so long, or overvalue the votes of hotheads or those who are easily dissatisfied because they always feel more strongly about the outcome of an election. See id.

180. See id. (discussing a range of voting requirements related to strength of interest); Melvyn $\mathrm{R}$. Durchslag, Salyer, Ball, and Holt: Reappraising the Right to Vote in Terms of Political "Interest" and Vote Dilution, 33 CASE W. REs. L. Rev. 1, 38-39 (1982) (stating that "'interest,' implicitly or explicitly, must be the touchstone of the Court's analysis" of several types of voting rights cases). 
election should be allowed to vote. ${ }^{181}$ The strength of one's economic interest was a proxy for the strength of one's interest in the outcome of an election. Modern residency requirements are similarly justified, with the underlying assumption that only those living within the geographic territory under the control of a governmental entity have enough of a stake in that entity to vote. ${ }^{182}$ Even those who question residency requirements do not quibble with the theory that the right to vote is tied to the strength of one's interest, just with the idea that residency is a good proxy for interest. ${ }^{183}$

The way we numerically weigh votes also correlates to the strength of voter preferences. ${ }^{184}$ For example, while the one person, one vote standard applies to local governmental bodies, it only does so to those that exercise "general governmental powers." ${ }^{85}$ This is because we would expect such governing bodies to affect everyone within their jurisdiction to more or less the same degree, and we would therefore expect those people to have more or less the same strength of preferences with regard to the choice of representatives. The same would be true with respect to Congress or state legislatures, which also exercise general powers.

But what about governmental entities that do not exercise general governmental powers? They are treated differently under the Constitution. The Supreme Court first signaled this possibility in Avery v. Midland County, stating:

Were the Commissioners Court a special-purpose unit of government assigned the performance of functions affecting dcfinable groups of constituents more than other constituents, we would have to confront the question whether such a body may be apportioned in ways which give greater influence to the citizens most affected by the organization's functions. ${ }^{186}$

181. See KEYSSAR, supra note 6, at 5, 131; Hayden, supra note 4, at 249.

182. Hayden, supra note 4, at 249, 256-57; see Glenn P. Smith, Note, Interest Exceptions to OneResident, One-Vote: Better Results from the Voting Rights Act?, 74 TEx. L. Rev. 1153, 1159 (1996) (explaining that, in the 1960s, residency became "the sole proxy for electoral interest" and, in most cases, it became the sole "standard for granting suffrage to qualified potential voters").

183. For instance, in Holt Civic Club v. City of Tuscaloosa, the Court explained: "The imaginary line defining a city's corporate limits cannot corral the influence of municipal actions. A city's decisions inescapably affect individuals living immediately outside its borders." 439 U.S. 60,69 (1978). See also Richard Briffault, The Local Government Boundary Problem in Metropolitan Areas, 48 STAN. L. REv. 1115, 1132 (1996) ("Boundaries exclude people who may be interested in or affected by the decisions made within the boundaries.").

184. See Hayden, supra note 4, at 257.

185. See, e.g., Hadley v. Junior Coll. Dist., 397 U.S. 50, 54 (1969) (applying the equiproportional standard to a junior college district); Avery v. Midland County, 390 U.S. 474, 484-85 (1967) (applying the equiproportional standard to a county government).

186. 390 U.S. at $483-84$. 
The Court soon dealt with the status of such special-purpose districts in a case involving the governing board of a California water district. ${ }^{187} \mathrm{~A}$ board of directors, whose members were elected by landowners (not residents), governed the water district. Their votes were weighted according to the amount of land they owned (sort of a one acre, one vote system). ${ }^{188}$ The Court found that, because the board's powers disproportionately affected landowners and did so in proportion to the amount of land owned, the water district's voting scheme was constitutionally exempt from the one person, one vote requirement. ${ }^{189}$ Thus, we allow deviations from the one person, one vote standard when there is better information about the relative strength of people's preferences. ${ }^{190}$

As a descriptive matter, then, we correlate the right to vote (and to have one's vote accorded a certain weight) to preference strength. Applying the one person, one vote standard is partly based on the general assumption that everyone has an equal interest in the outcome of an election. But the assumption of equal interest is problematic because it requires making a judgment as to the relative strength of different people's preferences, which, in turn, brings us back to the problem of making interpersonal utility comparisons. ${ }^{191}$

As 1 have explained at some length in a previous Article, ${ }^{192}$ the problem with making comparisons between different people's utility levels is that we have no neutral or objective way to make such judgments. ${ }^{193}$ As Lionel Robbins recognized in the early 1930s:

There is no means of testing the magnitude of A's satisfaction as compared with B's. If we tested the state of their blood-streams, that would be a test of blood, not satisfaction. Introspection does not enable A to measure what is going on in B's mind, nor B to measure what is going on in A's. There is no way of comparing the satisfactions of different people. ${ }^{194}$

187. Salyer Land Co. v. Tulare Lake Basin Water Storage Dist., 410 U.S. 719 (1973). Nearly a decade later, the Court confronted another water district and reasoned in a similar way. See Ball $v$. James, 451 U.S. 355 (1980).

188. Salyer, 410 U.S. at 724 .

189. Id. at 729-34.

190. See Hayden, supra note 4 , at 251-55.

191. Utility, for these purposes, can be equated with preference satisfaction. See id. at 236-37.

192. See id. at 236-47.

193. There are several works that give a good background to this problem. See, e.g., JAMES GRIFFIN, WELL-BEING 113-20 (1986) (stepping through some of the more obvious problems); InTERPERSonal Comparisons of Well-Being (Jon Elster \& John E. Roemer eds., 1991); Peter J. Hammond, Interpersonal Comparisons of Utility: Why and How They Are and Should Be Made, in INTERPERSONAL COMPARISONS OF WELL-BEING, supra, at 200, 238-54 (providing a particularly useful bibliography).

194. Lord Robins, An Essay on the Nature and Significance of Economic Science 139 40 (3d ed. 1984) (emphasis omitted). Robbins's point was not new, see, e.g., W. Stanley Jevons, The 
Robbins's point was not that there was no way of making interpersonal comparisons, but that there was no way based on the kind of objective, verifiable evidence that he and other economists desired. ${ }^{195}$ Without such evidence, many economists structured their views of social welfare in ways that avoided making such comparisons. ${ }^{196}$

Other philosophers and economists attempted to solve the problem by trying to find a way to make objective interpersonal comparisons of utility. But, in short, they failed. One way to solve the problem is to find a universal scale upon which to measure everyone's satisfaction. But no such scale exists and, even if it did, there is no omniscient social scientist with the ability to peer into everyone's minds and make assessments. ${ }^{197}$ A second way to solve the problem is to turn interpersonal comparisons into intrapersonal ones, which are, by most accounts, easier to compare. ${ }^{198}$ There are several variations to this approach, but they all involve attempts to put oneself into another's shoes in order to make a direct comparison. ${ }^{199}$ Ultimately, though, this approach fails as well, for, to the extent I can put myself in another's shoes, there is less of "me" left to make the comparison. ${ }^{200}$

TheORY OF Political ECONOMy 14 (5th ed. 1965), but it captured the minds of several generations of political economists.

195. See RoBB1NS, supra note 194, at 140-41.

196. See Martin Barrett \& Daniel Hausman, Making Interpersonal Comparisons Coherently, 6 ECON. \& PHIL. 293, 293 (1990). For a brief sketch of the history of the avoidance of interpersonal utility comparisons, see Hammond, supra note 193, at 204-07. See also Amartya Sen, Social Choice Theory, in 3 Handbook of Mathematical Economics, 1073 (Kenneth J. Arrow \& Michael D. Intriligator eds., 1986) (providing a useful survey of the literature of social choice theory without interpersonal comparisons).

197. See Hayden, supra note 4, at 245; Daniel M. Hausman, The Impossibility of Interpersonal Utility Comparisons-A Reply, 106 Mind 99, 99 (1997).

198. See Daniel M. Hausman, The Impossibility of Interpersonal Utility Comparisons, 104 MIND 415, 477-78 (1995); Alfred F. MacKay, Extended Sympathy and Interpersonal Utility Comparisons, 83 J. PHIL. 305, 305-06 (1986).

199. Alfred MacKay tcrms such attempts the "mental shoehorn maneuver." MacKay, supra note 198, at 305. See also R. M. Hare, Moral. Thinking 87-106, 117-29 (1981); John C. Harsanyi, Rational Behavior and Bargaining Equilibrium in Games and Social Situations 58-59 (1977); Kenneth J. Arrow, Extended Sympathy and the Possibility of Social Choice, 67 AM. EcoN. REv. 219, 223-37 (1978); John C. Harsanyi, Morality and the Theory of Rational Behavior, 44 Soc. RES. 638 (1977). Arrow, however, admits that there are some lurking problems in the approach:

[1]f your satisfaction depends on some inner qualities that $I$ do not possess, then $I$ really have not had the experience which will enable me to judge the satisfaction one would derive from that quality in association with some distribution of goods. Hence, my judgment has a probability element in it and therefore will not agree with your judgment.

Kenneth J. Arrow, Extended Sympathy and the Possibility of Social Choice, 7 Philosophia 223, 236 (1978). There are, of course, other adherents. See, e.g., AMARTYA SEN, ON ECONOMIC INEQuality 1415 (1973); Donald Davidson, Judging Interpersonal Interests, in Foundations of Social Choice THEORY 195 (Jon Elster \& Aanund Hylland eds., 1986).

200. See MacKay, supra note 198, at 321-22; see also James Griffin, Against the Taste Model, in INTERPERSONAL COMPARISONS OF WELL-BEING, supra note 193, at 45, 52-59. 
The lesson, though, is not that objective interpersonal utility comparisons cannot be made, but that they necessarily involve normative decisions. ${ }^{201}$ In other words, when one assigns weight to a person's preferences, one makes some fundamental value judgments. Similarly, there is no objective standard of quantitative vote dilution that ties the weight of each person's vote to the intensity of her preference. ${ }^{202}$ The one person, one vote standard has no greater claim to this sort of neutrality than any other standard, for we have no objective reason for thinking that everyone within a certain jurisdiction has identically strong preferences with respect to the outcome of an election. ${ }^{203}$ It involves the same sort of normative considerations at issue in the access cases and, more to the point, in the qualitative vote-dilution cases. ${ }^{204}$

The fact that the one person, one vote standard involves a normative judgment should not be that controversial. The Justices who dissented from the original malapportionment cases made a similar point. ${ }^{205}$ Academics, too, recognized that the standard was a normative one. ${ }^{206}$ Despite that recognition, we have not reexamined the standard with an eye to solving current problems in minority vote dilution. But its essentially normative character makes it fair game when it comes to tinkering with democratic institutions. And, it may provide a key to resolving the dilemma of minority representation.

III

\section{Resolving the Dilemma of Minority Representation}

\section{A. A Partial Solution}

Once we get over the illusion that the one person, one vote standard is neutral or objective, the right to cast a ballot free from quantitative vote dilution begins to look a lot like other aspects of voting rights. This is especially true when we recognize that departures from perfect equality can already be justified by respect for existing political subdivisions, communities of interest, and other factors. ${ }^{207}$ Assigning the correct numerical weight to votes involves making the same normative decisions as granting access

201. See John Broome, Weighing Goods: Equality, Uncertainty and Time 220 (1991); GRIFFIN, supra note 193, at 119-20; Hammond, supra note 193, at 226, 236-37; Hayden, supra note 4, at 246-47; Thomas M. Scanlon, The Moral Basis of Interpersonal Comparisons, in INTERPERSONAL COMPARISONS OF WELL-BEING, supra note 193, at 17, 18, 44.

202. See Hayden, supra note 4, at 247-51.

203. See id. at 251-52.

204. See id. at 255-61.

205. See, e.g., Baker v. Carr, 369 U.S. 186, 268 (1962) (Frankfurter, J., dissenting) (speaking of the "incommensurable factors of policy that underlie these mathematical puzzles").

206. See, e.g., HASEN, supra note 4, at 21-25.

207. See, e.g., Karcher v. Daggett, 462 U.S. 725, 740-41 (1983); Reynolds v. Sims, 377 U.S. 533, $577-81$ (1964). 
to the polls, ${ }^{208}$ or deciding to draw district lines in a way that maximizes or minimizes the voting power of a particular group. ${ }^{209}$ This has many possible implications for the way voting rights should be legally structured.

Treating one person, one vote claims like other voting-rights claims could take us in one of three directions when it comes to judicial involvement in voting rights. First, one could argue that courts should be allowed more freedom to intervene in and decide voting-rights controversies. The argument here would be that we have already allowed courts, without much of a pretext, to make substantive political decisions in the one person, one vote cases. Allowing more intervention in the access and gerrymandering cases really is not granting courts a qualitatively different role in the political process. Second, one could go the other way on the question of judicial involvement and say that this is an argument for the courts to get out of the business of voting rights in all but the most extreme cases. Justice Frankfurter was right in more ways than one when he said that the malapportionment cases involved a step into the political thicket. ${ }^{210}$ Initially, the decision to hear quantitative vote-dilution claims involved normative political judgments. Moreover, it opened the door with respect to other, more judicially invasive forays into the types of decisions usually reserved for legislatures (as Hasen put it, Reynolds $v$. Sims begat Bush v. Gore). ${ }^{211}$ The one person, one vote claims ended up serving as a pretext for court involvement in qualitative vote-dilution decisions, which, in an even more transparent way, involved substantive political decisions. ${ }^{212}$ Thus, one could argue that courts should step back from the original one person, one vote cases, or at least apply the standard in a more flexible fashion. This would get courts out of the business of making political judgments that they are so ill-equipped to make. Finally, we could also argue for taking a middle path, one allowing judicial involvement in some types of voting rights cases and, once the judges are in, give them a freer hand to devise reinedies. ${ }^{213}$

208. See Hayden, supra note 4, at 255-61.

209. See id. at 259-61.

210. See Colegrove v. Green, 328 U.S. 549, 556 (1946).

211. Richard L. Hasen, $A$ "Tincture of Justice": Judge Posner's Failed Rehabilitation of Bush v. Gore, 80 Tex. L. Rev. 137, 154 (2001) (reviewing Richard A. Posner, Breaking the Deadlock: The 2000 Election, the Constitution, AND the Courts (2001)).

212. See Karcher v. Daggett, 462 U.S. 725, 778 (1983) (White, J., dissenting); Karlan, supra note 154, at 735; Karlan, The Rights To Vote, supra note 5, at 1730.

213. This increased freedom would help recapture the rationales for judicial intervention found in the Carolene Products footnote from the partisan interests that have commandeered them for their own purposes. See United States v. Carolene Prods. Co., 304 U.S. 144, 152 n.4 (1938). Nate Persily persuasively deseribes the cooption of these prominority and anti-entrenchment rationales in the service of normal partisan eonflict. See Persily, supra note 129, at 610-12. Relaxing the application of the one person, one vote standard in all contexts (which 1 support, but is not the central thesis of this Artiele) would help remove it from the parties' general litigation arsenals. As discussed below, the proposal in this Article would not quite do that, but it would redirect aspects of the one person, one vote law in the 
The three types of voting-rights claims involve the same sorts of normative issues and should therefore be viewed more interchangeably. Because of the Court's role in checking a potentially tyrannical majority, one area ripe for this type of judicial intervention is that of minority voting rights. Here, a relaxation of the one person, one vote standard can lead us out of the representation dilemma faced by minority voters. ${ }^{214}$

Our previous conclusions can now help us move forward. We already know that strict adherence to the one person, one vote standard is one of the necessary conditions for the dilemma faced by minority-voting-rights advocates. We also know that such quantitative claims involve decisions that are every bit as normative as those found in other types of voting rights claims. That said, when faced with a qualitative minority-votedilution claim, legislatures and, if necessary, courts should be able to manipulate both the shape and the relative population of the district in order to strengthen minority political participation. In the context of minorityvote-dilution claims, in addition to redrawing district lines in a way that creates majority-minority districts, we could allow plaintiffs to propose (and courts to approve) remedial plans that reduce the numerical size of those districts to further concentrate minority voting power. This would give voting rights plaintiffs additional tools to use in their quest for more effective participation.

Let us revisit the simplified example used earlier to demonstrate how this could be done. ${ }^{215}$ In that example, remember, District A and District B each had 100,000 voters composed of 35,000 black voters and 65,000 white voters. Black voters supported Democrats over Republicans at a ratio of $90 \%$ to $10 \%$; white voters supported Republicans over Democrats at a ratio of $60 \%$ to $40 \%$. As a result, both districts sent a white Democrat to the legislature. The creation of a majority-minority district allowed those in a redrawn District $A$ to elect a black Democrat, but at the cost of electing a Republican in District B. Hence, there is a tradeoff between descriptive and substantive representation.

But without the constraints of the one person, one vote standard, one can create a majority-minority district without losing much in the way of substantive representation. For example, District $\mathrm{A}$ could be redrawn as a much smaller majority-minority district-say with a population of 50,000 , with 30,000 black voters and 20,000 white voters. Such a district, as in the first example, would elect a black Democrat, this time by a margin of

service of those discrete and insular minorities about whom the Carolene Products Court was concerned.

214. See Hayden, supra note 4, at 264-65 (noting the possibility of reducing the population of majority-minority districts to numerically concentrate minority voting strength); GROFMAN ET AL., stipra note 6, at 110-11 (discussing the relationship between the equal population requirement and minority representation).

215. See supra note 96 and accompanying text. 
35,000 to $15,000 .{ }^{216}$ This leaves District B with 150,000 voters: 40,000 black and 110,000 white. District $B$, though, unlike the last example, would again elect a white Democrat, now by a margin of 80,000 to $70,000 .{ }^{217}$ The freedom to manipulate district population, along with district shape, would allow a court (or the DOJ) to remedy a case of qualitative vote dilution without the attendant loss of substantive representation.

This example, with its resulting three-to-one population disparity, may seem a bit extreme, but the point it makes is not. To begin with, one should recognize that some of our most hallowed democratic institutions, such as the U.S. Senate, give rise to much larger differences in voting power. ${ }^{218}$ There are many reasons, beyond the one dealt with here, for rethinking the precise adherence to the one person, one vote standard required of congressional districts. ${ }^{219}$ And, as mentioned above, we usually allow state and local districts to deviate up to $10 \%$ from the standard without question, and even more if suitably justified. ${ }^{220}$ Chief among the reasons currently used to justify higher deviations is the maintenance of existing district lines-lines that, as Richard Ford has persuasively argued, are already strongly informed by race. ${ }^{221}$ Given all of this, allowing deviations from the one person, one vote standard in order to more effectively remedy the dilution of minority voting power is a perfectly appropriate solution.

Despite the fact that the one person, one vote standard is well entrenched in the popular imagination, it may also be the solution that involves the smallest amount of legal change. Three somewhat related changes would need to occur, all three of which have justifications completely independent from the issue of minority vote dilution. First, the Supreme Court would need to back out of the line of cases holding that congressional districts within the same state must be perfectly equiproportional. This would not mean going back on the reasoning of Baker $v$.

216. The 35,000 figure for the Democrats comes from $90 \%$ of 30,000 black voters $(27,000)$ plus $40 \%$ of 20,000 white voters $(8000)$.

217. The 80,000 figure for the Democrats comes from $90 \%$ of 40,000 black voters $(36,000)$ plus $40 \%$ of 110,000 white voters $(44,000)$.

218. Under our constitutional structure, the two senators from Wyoming represent 495,304 people while the two from California represent 33,930,798. See Karen M. Mills, U.S. Census Bureau, Congressional Reapportionment 2 tbl.1 (July 2001). For some critiques of this aspect of the Senate, see Robert A. Dahl, How Democratic Is the American Constitution? 46-54 (2002); Suzanna Sherry, Our Unconstitutional Senate, in Constitutional Stupidities, Constitutional Tragedies 95 (William N. Eskridge, Jr. \& Sanford Levinson eds., 1998).

219. They have been criticized for, among other things, using the wrong apportionment base, having their precise toleranees swamped by imperfections in census data, and doing little to ensure equal political opportunity. See Hayden, supra note 4, at 230-34.

220. See supra notes $42-43$ and accompanying text.

221. See Richard Thompson Ford, The Boundaries of Race: Political Geography in Legal Analysis, 107 HARV. L. REv. 1841 (1994). 
Carr, $^{222}$ nor would it mean tossing out Wesberry $v$. Sanders. ${ }^{223}$ Congressional districts would still be held to the one person, one vote standard-they would just be allowed a greater degree of variation, one that comports with the imprecision in census data, the existing differences between districts in different states, ${ }^{224}$ and more effectively resolving minority vote dilution. ${ }^{225}$

Second, along with backing away from strict application of the standard, we would need to allow states, the DOJ, or courts to use the problem of minority representation discussed in this article to justify deviations from the one person, one vote standard. In the case of state legislative districts, this would mean just adding it to the list of acceptable reasons for a deviation. For congressional districts it would require creating a meaningful list and making this item the first on the list (though, one hopes, not the last). While the Court has made clear that some consistently applied legislative policies might justify small deviations in a voting district's population, ${ }^{226}$ it expressly reserved the question of whether preserving minority voting strength is one of those policies. ${ }^{227}$ Thus, the general structure for this aspect of the solution already exists in the area of state reapportionment decisions; the precise details involving the maximum allowable deviation for such purposes can be based on the problem that racial redistricting is designed to solve.

The final hurdle is also constitutional and involves the Shaw line of cases. ${ }^{228}$ Reducing district relative population in order to numerically concentrate minority voting power may run afoul of Shaw and, more directly, Miller v. Johnson's proscriptions against allowing race to predominate districting decisions. ${ }^{229}$ But, again, the analysis here should not be any

222. 369 U.S. 186 (1962) (finding differences in state legislative district sizes to be a justiciable issue).

223. 376 U.S. 1 (1964) (applying the one person, one vote standard to congressional districts).

224. The constitutional requirement that representatives be apportioned among the several states means that congressional districts do not cross state lines. From this, it follows that the Court's standard of "precise mathematical equality" only applies to districts within a single state. Kirkpatrick v. Preisler, 394 U.S. 526, 530-1 (1969). Aftcr the most recent round of redistricting, this, coupled with the onerepresentative per state minimum, means that while the congressional district in Wyoming has a population of 495,304 , the one in Montana has 905,316 . See Mills, supra note 218 , at 1, 4 . The average district size is 646,952 . Id. at 1 .

225. There are all sorts of reasons for relaxing application of the one person, one vote standard, especially in light of some of the Supreme Court's other voting-rights decisions. See Grant M. Hayden, The Supreme Court and Voting Rights: An Incomplete Exit Strategy, 83 N.C. L. REv. (forthcoming May 2005).

226. See Karcher v. Daggett, 462 U.S. 725, 740-41 (1983).

227. See id. at 742-43 \& n. 12 .

228. See Miller v. Johnson, 515 U.S. 900 (1995) (holding that districts may violate the Equal Protection Clause of the Constitution if race was the predominant factor in their creation); Shaw $v$. Reno, 509 U.S. 630 (1993) (holding that irregularly shaped districts can, on their face, violate the Equal Protection Clause of the Constitution).

229. See Miller, 515 U.S. 900. 
different than in the gerrymandering cases. That is, manipulating district relative population should not be subject to any higher standard than manipulating district shape. There are many other possible considerationssuch as protecting incumbents, maximizing party control, and maintaining existing governmental boundaries-that would provide additional reasons for any decision to reduce or increase district relative population. The Supreme Court, as of late, appears to be more willing to allow that these other considerations may have as much to do with a redistricting decision as race. ${ }^{230}$ Thus, though this solution of loosening up the one person, one vote standard may sound somewhat extreme, it would not involve anything close to a complete reworking of our majoritarian democratic structures (like cumulative voting) or even significantly revamping existing votingrights law.

\section{B. Responses to Possible Objections}

Although this solution does not demand a radical change in the country's democratic structures (or even most of its voting rights laws), it does require revising the right to an equally weighted vote. Likc any revision of a well-established norm, it gives rise to a host of complicated issues. First, by demanding the creation of smaller majority-minority or coalition districts, the solution assigns greater weight to minority votes in what appears to be a rather crude form of affirmative action: it straightforwardly gives blacks and Hispanics more numerical voting power than whites. Second, unlike equipopulous racial gerrymandering, which is cabined by both geography and constitutional doctrine, the quantitative improvement of voting power lacks obvious limits. One can imagine devising smaller and smaller districts in order to further concentrate minority voting power. Third, the solution may give rise to new forms of partisan manipulation that are damaging in their own right or, at a minimum, thwart the goal of remedying minority vote dilution. Fourth, and finally, the sheer inertia of the one person, one vote standard may stand in the way of judicial acceptance of the solution.

Given the chilly reception offered to racial gerrymanders that qualitatively concentrated minority voting power, one can only imagine the outcry at quantitatively concentrating minority voting power as well. The solution does involve a form of affirmative action, as it proposes race-conscious alteration of district relative population in order to concentrate minority voting power. And affirmative action in the context of voting rights seems more troubling than in other areas, such as school admissions or employment, in that it involves tinkering with what it means to be a member of a political majority or minority.

230. See Easley v. Cromartie, 532 U.S. 234 (2001) (sustaining redistricting, based partially on race, because other factors were at play in the decision) 
But this solution should not add any more fuel to the flame of the affirmative action debate. While it is true that we do not currently manipulate the relative population of districts (and quantitatively concentrate voting power) to further the goal of effective minority representation, we do manipulate the shape (and qualitatively concentrate it). And, as I have argued here and elscwhere, ${ }^{231}$ quantitative and qualitative concentration and dilution involve the same sort of normative considerations. One can affect the outcome of an election by assigning votes different weights or by combining votes in different ways. Both aspects of the right to vote involve the manipulation of group voting power. In other words, the issue here should not be any different than the issue with respect to the racial gerrymanders that give rise to majority-minority or coalition districts. While manipulating the relative population of districts may renew the debate over affirmative action in voting rights, the only real change would be in the tone, not the substance, of the debate.

One should also remember that the numerical concentration of voting power is only proposed in anticipation (or as a remedy) to a vote-dilution claim under section 2 or to prevent retrogression under section 5 of the Voting Rights Act. Congress made the decision to concentrate on the rights of racial and Ianguage minorities. And Congress made this decision in order to realize the guarantees of the Fifteenth Amendment. The solution, then, does not randomly select minority groups for some sort of special treatment; instead, it helps fulfill the constitutional promise of voting equality and satisfy the legislation designed to enforce it.

Allowing states to comply with (and courts to enforce) the dictates of the Voting Rights Act by manipulating the relative population of districts does not substantively enlarge the scope of the injury that the Act is designed to remedy-it just adds another way of ensuring compliance. This is so despite the fact that it would increase the number of situations in which actionable vote dilution could be found (and would do so without the representational costs discussed above). Take, for example, a vote-dilution claim under section 2 of the Act. Members of a protected minority group need to show that they have "less opportunity than other members of the electorate to participate in the political process and to elect representatives of their choice."232 They can make this showing by proving that (I) they are sufficiently large and geographically compact to constitute a majority in a single-member district, (2) they are politically cohesive, and (3) the majority votes as a bloc in such a way that it usually defeats the minority's preferred candidate. ${ }^{233}$ The second two prongs map out the legal injury, and I do not think my proposal has any direct effect on them. It does affect the

231. Hayden, supra note 4, at 254-61.

232. 42 U.S.C. $\$ 1973$ (b) (2000).

233. See Thomburg v. Gingles, 478 U.S. 30, 50-51 (1986). 
first prong, in that it would allow plaintiffs to demonstrate that they constitute a majority in a district with a smaller population (up to some limit). But this first prong, when coupled with the second, mainly serves to map out the remedy, not the injury. Thus, the proposal does not involve much more than identifying potential vote dilution under current standards and then allowing the manipulation of district relative population as a remedy.

A second potential shortcoming of my solution is that it lacks appreciable limits. The primary remedy for qualitative vote-dilution claimsredrawing district lines to form majority-minority or coalition districtshas some built-in limitations. Initially, the requirement that election districts be contiguous, coupled with the geographic distribution of blacks and Hispanics, places an upper limit on the number of majority-minority districts that can be drawn. And, as seen earlier, the reapportionments of the 1990s came quite close to those limits. In addition, the Supreme Court placed an additional check on district shape in Shaw, finding a constitutional violation when a district shape is so bizarre that it cannot be explained by anything other than race. Though the Court later clarified that district shape was more of an evidentiary matter than a strict substantive rule, shape restrictions still place limits on the number of majority-minority districts. And, of course, the one person, one vote requirement also functions to control the number of minority districts.

But once the one person, one vote standard is relaxed in this context, there is no obvious limit to the number of majority-minority districts that could be drawn. In a move that could make the "max-black" push of the 1990s look like child's play, one could theoretically litter the political landscape with very small districts with relatively large minority populations. Minority-preferred candidates could dominate Congress and state legislatures. Even though shrinking majority-minority districts would only occur in anticipation of or as a remedy for a claim under the Voting Rights Act, it is sometimes hard to separate remedy from harm in voting-rights cases. The three-pronged test in Gingles, remember, encapsulated both injury and remedy and effectively gave minority plaintiffs a cause of action under section 2 whenever there was racial bloc voting and they could be drawn into a compact majority-minority district. Thus the obvious question: Where would we draw the line when it came to disparities in district population?

As in the current qualitative vote-dilution cases, this is a question for which there is no simple answer. It instead appears to be one of those areas where, in the absence of a clear consensus, it would be best for the Court to give legislatures (and lower courts) the doctrinal flexibility and the time to slowly develop an answer rather than rushing to draw some bright-line outer limit that may prove unworkable in the long run. So while there are no easy answers, there may be some obvious starting points that could be 
used to rough out the outer boundaries of acceptable district relative population.

For example, in the case of congressional districts, one could set the limits at the smallest and largest district populations dictated by the constitutional requirement that districts not cross state lines. ${ }^{234}$ That requirement currently means that while the average population of congressional districts is 646,952 , the population of the district in the state of Wyoming is $495,304 .{ }^{235}$ Thus, the population in the least-populous state could be used to set a minimum for district population in states with more districting flexibility. The maximum district population could be set in the same way, with Montana's 905,316 setting the upper limit. ${ }^{236}$ These types of boundaries would ensure that any new, smaller minority districts would not cause numerical dilution that is much out of line with that currently caused by Wyoming. Within those outer boundaries, one could additionally use a test of rough proportionality to limit the number or relative population of majority-minority districts. In a state with ten congressional seats where blacks make up $28 \%$ of the population, for example, drawing more than three majority-black districts may lead to some level of constitutional suspicion.

The point here is not that there is a clear lower limit to acceptable district population, but that the issues are not qualitatively different than those in the current debate over racial gerrymandering. While that may not warm the hearts of those familiar with the Supreme Court's slipshod voting rights jurisprudence, it should not add any additional chill. Both redrawing district lines and changing relative district population involve making substantive political decisions. And, in light of the normative character of the one person, one vote standard, that is exactly what we should expect.

A third potential drawback to the proposed solution is that it will be subject to partisan manipulation. In addition to being able to gerrymander the shape of districts in order to advantage their political fortunes, parties would again be able to play with relative district population as well. The mere possibility of being able to tinker with relative district population should be enough to make any political operative salivate, and perhaps that should make us somewhat wary of instituting such a change.

While it is clear that loosening the one person, one vote standardeven in the limited circumstances of minority vote dilution-would give political parties additional opportunities to advance their own interests, this would be true of almost any change in the laws governing elections. The question then becomes not whether, but how, parties will likely respond to this change. And, while predicting the form and effect of party behavior is

234. See U.S. Const. art. 1, § 2, cl. 3.

235. See MILls, supra note 218 , at 1,4 .

236. See id. at 4. 
quite difficult, there are some reasons to believe that this proposal would be well worth the cost of any additional partisan manipulation.

The most obvious effect would be to realign the political philosophies of the two main political parties with their own self-interests. Democrats would be in a position to push for additional majority-minority districts without sacrificing Democratic seats; Republicans would, in all likelihood, oppose such districts. Both parties could pursue their own electoral selfinterest without fear of contradicting their stated ideology on matters of race.

Such a realignment of party self-interest with party ideology is not necessarily desirable. Perhaps it is useful to have a system that extracts some political cost when parties engage in racial gerrymanders that benefit their candidates. Aligning the interests of Republicans with those of many minority groups may provide some additional political capital to minority incumbents. It may even change some people's minds, one way or another, about the value of race-conscious legislation. If nothing else, the current system may simply provide a check on the incentives of both parties to manipulate the system. Perhaps this works in favor of minority-votingrights advocates, who may be able to form alliances with both major parties: the Democrats for ideological reasons, the Republicans for selfinterested ones. Both political parties have something to gain by supporting the creation of majority-minority districts.

But both have something to lose as well. Democrats may reap some political gain by catering to the interests of some of their most loyal supporters, but may ultimately lose some legislative seats. Republicans may gain some seats, but may also alienate some of their supporters by throwing their weight behind race-conscious legislation. Neither party has an unconflicted interest that matches up with that of minority voters. For example, Democrats in Georgia, including black incumbents from newly drawn majority-minority districts, closed ranks in their most recent round of redistricting to undermine the strength of some majority-minority districts. And leaving Republicans in charge of championing minority interests under the Voting Rights Act is clearly leaving the fox in charge of the henhouse. Neither party is neutral, even on the issue of solving minority vote dilution for its own sake, and that may be a problem any time party interests and minority voter interests diverge. It may be better for minority voters, then, to line up at least one of the parties' ideologies with its selfinterest.

Of the two parties, the Democrats would be clear beneficiaries of a relaxation of the equiproportional rule. Newly created majority-minority districts would not necessarily deprive surrounding districts of reliably Democratic voters. Minority districts could therefore be created without representational costs to Democrats. This result, however, should not be 
surprising. The Voting Rights Act was created to ensure that minority voters could fully participate in the political system. Those voters overwhelmingly support Democratic candidates. The fact that a remedy for minority vote dilution under the Voting Rights Act favors the interests of the Democratic party, therefore, should be expected. It certainly makes more sense than one that has an effect of helping Republicans.

A more general concern is that parties may be able to manipulate relative district population in a way that leads to the kind of political entrenchment that Baker and its progeny were designed to eliminate. That is, a party or faction would use this as an opening to seize control of Congress or a state legislature and lock up the political system. This, in turn, would give rise to all of the negative consequences that flowed from the malapportionment of the first half of the twentieth century.

But there is little likelihood that merely relaxing the one person, one vote standard in the context of minority vote dilution would lead us back to those pre-Baker variations in relative district population. Relaxing the standard is not eliminating the standard: the one person, one vote norm would still be the benchmark and deviations from that norm would need to be suitably justified. As discussed above, the Court could establish outside limits to maximum deviation from the norm. Even allowing differences in numerical voting power of up to two to one would allow much more districting flexibility without coming close to the differences at issue in Baker (twenty to one) and Reynolds (forty-one to one). Thus, while it may be impossible to predict all possible unintended consequences of such a move, there seems to be a sufficient backstop in place to prevent the type of redistricting problems that plagued the pre-Baker political landscape.

A final hurdle in implementing the proposed solution is not legal or political, but more social and psychological. Given the popularity of the one person, one vote standard, is it even conceivable that we could, for any reason, pull back from it? For example, Hasen argues:

$[\mathrm{N}]$ othing now formally prevents the Court from backpedaling from a decisive standard like the one person, one vote standard,.... [M]y sense is that a move from a mushy unmanageable standard to a more manageable standard is easier for the Court than to overrule existing precedent or even to make an unannounced switch from a firm manageable standard to mushiness. $^{237}$

And while giving credence to this type of argument appears to stand in the way of almost any legal change, there must be some appreciation of whether a proposal is even within the realm of the possible.

There are several reasons to think that allowing the numerical concentration of minority voting power is a realistic answer to some of the issues 
of minority vote dilution. 1 do not propose eliminating the one person, one vote standard as one of the benchmarks of political equality. Instead, the solution here only involves relaxing the application of the standard in a way that comports with the structure of existing voting-rights law. Thus, this is not a call to eliminate one person, one vote from our political vocabulary, but to assign it a more nuanced role in recognition of its essentially normative character.

Nor would such a move be likely to spark widespread resentment. For example, there is already plenty of judicial and academic grumbling about the precise tolerances built into the Court's application of the one person, one vote standard. Although it is clear that the public has wholeheartedly embraced the one person, one vote slogan, there is little reason to believe that it would be upset by a relaxation of the standard. Nobody seems too upset by the enormous differences in voting power presented by the Senate, much less about the differences engendered by the fact that congressional districts do not cross state lines. And, after the dust cleared in the 2000 presidential election controversy, most people did not seem to mind that the electoral college resulted in the election of a candidate with half a million fewer votes than his opponent. Thus, despite the popularity of the one person, one vote standard, there is no reason to believe that strict adherence to it is so firmly entrenched in judicial philosophy or public consciousness to render the proposed solution a nonstarter.

\section{CONCLUSION}

The dilemma of minority representation has a very real effect on the way our democracy functions. It explains why there has been a limit to the number of black and Hispanic representatives elected. It explains how the quest to increase minority representation contributed, somewhat perversely, to the rising fortunes of the Republican candidates through the 1990s. And it represents the next, though assuredly not the last, major challenge in the field of minority voting rights.

The dilemma is the result of many historical and demographic forces. Members of racial minority groups overwhelmingly support Democratic candidates, whites increasingly support Republicans, and the racial divide in politics is growing. While that situation, and the underlying problem of race in this country that it represents, does not lend itself to a ready legal solution, there are other grounds for the dilemma that may be more easily remedied. Chief among these is the slavish adherence to the one person, one vote standard, which, both literally and figuratively, makes the creation of majority-minority districts a zero-sum game.

Allowing departures from the one person, one vote standard in the remedy phase of minority-vote-dilution cases would remove one of the necessary conditions of the representation dilemma. It would allow the 
DOJ and the courts to create majority-minority districts, and therefore increase descriptive representation without substantively penalizing minority voters. And, in doing so, it would resolve the most pressing issue in this "Second Reconstruction": the dilemma of minority representation. 
[Vol. 92:1589 